\title{
Elevation and elevation change of Greenland and Antarctica derived from CryoSat-2
}

\author{
V. Helm, A. Humbert, and H. Miller \\ Glaciology Section, Alfred Wegener Institute, Helmholtz Centre for Polar and Marine Research, Bremerhaven, Germany \\ Correspondence to: V. Helm (veit.helm@awi.de)
}

Received: 1 February 2014 - Published in The Cryosphere Discuss.: 25 March 2014

Revised: 18 July 2014 - Accepted: 21 July 2014 - Published: 20 August 2014

\begin{abstract}
This study focuses on the present-day surface elevation of the Greenland and Antarctic ice sheets. Based on 3 years of CryoSat-2 data acquisition we derived new elevation models (DEMs) as well as elevation change maps and volume change estimates for both ice sheets. Here we present the new DEMs and their corresponding error maps. The accuracy of the derived DEMs for Greenland and Antarctica is similar to those of previous DEMs obtained by satellitebased laser and radar altimeters. Comparisons with ICESat data show that $80 \%$ of the CryoSat-2 DEMs have an uncertainty of less than $3 \mathrm{~m} \pm 15 \mathrm{~m}$. The surface elevation change rates between January 2011 and January 2014 are presented for both ice sheets. We compared our results to elevation change rates obtained from ICESat data covering the time period from 2003 to 2009. The comparison reveals that in West Antarctica the volume loss has increased by a factor of 3. It also shows an anomalous thickening in Dronning Maud Land, East Antarctica which represents a known large-scale accumulation event. This anomaly partly compensates for the observed increased volume loss of the Antarctic Peninsula and West Antarctica. For Greenland we find a volume loss increased by a factor of 2.5 compared to the ICESat period with large negative elevation changes concentrated at the west and southeast coasts. The combined volume change of Greenland and Antarctica for the observation period is estimated to be $-503 \pm 107 \mathrm{~km}^{3} \mathrm{yr}^{-1}$. Greenland contributes nearly $75 \%$ to the total volume change with $-375 \pm 24 \mathrm{~km}^{3} \mathrm{yr}^{-1}$.
\end{abstract}

\section{Introduction}

Ice sheet surface topography and changes thereof are of great interest to glaciologists for several reasons. Changes in surface elevation represent the response of an ice sheet to changes in ice dynamics and surface mass balance in an integrative way. Several digital elevation models (DEM) have been published for Greenland and Antarctica in the last 2 decades, e.g., (Liu et al., 2001; Bamber et al., 2009, 2013; Fretwell et al., 2013; Howat et al., 2014). These data sets provide important input for numerical flow modeling. Other applications range from field campaign planning to the estimation of driving stresses for ice sheet flow (Sergienko et al., 2014) to applications in InSAR processing. The latter is a technique widely used to derive mass balance estimates of glaciers and ice streams and requires an accurate and up-to-date DEM, to distinguish between the interferometric phase difference caused by topography and ice motion (Joughin et al., 2010a).

Furthermore continuous or repeated elevation measurements are used to estimate elevation changes. The required records can be obtained by operating satellite or airborne altimeters using laser or radar signals (Pritchard et al., 2009; Flament and Rémy, 2012). Measured elevation changes can serve as a validation for prognostic models simulating the recent evolution of ice sheets. Elevation change estimates are also used to assess the mass balance of the ice sheets, considering additional information such as firn densification and accumulation (Zwally et al., 2011; Shepherd et al., 2012).

Ice surface elevation change estimates based on altimetry data have been presented in the past for both regional and global scales. Pritchard et al. (2009); Smith et al. (2009); Sørensen et al. (2011); Ewert et al. (2012b) presented changes at the margins of Greenland and Antarctica based on 
laser altimetry data acquired by NASA's ICESat in the period between 2003 to 2009 . The strength of the ICESat data is their high single point as well as the repeat track accuracy. The single point accuracy of the measured elevation is usually within $0.1 \mathrm{~m}$ to $0.15 \mathrm{~m}$ and the separation between repeated-tracks is within a few hundreds meters (Shuman et al., 2006). In combination with the small footprint (diameter $70 \mathrm{~m}$ ) this results in low slope-induced errors (Fricker, 2005; Brenner et al., 2007). However, laser measurements are affected by clouds and might be disturbed by drifting snow, causing data gaps and interrupted time series. Furthermore the large across-track spacing prohibits observations of small-scale spatial patterns.

Another source of elevation measurements over the ice sheets are radar altimeters carried by the ESA satellites ERS1/2 and ENVISAT, which have been operating since the early nineties. The radar altimeter measurements are not affected by clouds and therefore enable continuous observations. However, in contrast to the ICESat instrument, which covers the polar region up to the latitude $86.0^{\circ} \mathrm{S} / \mathrm{N}$, ERS $1 / 2$ and ENVISAT are limited to latitudes between $81.5^{\circ} \mathrm{S}$ and $81.5^{\circ} \mathrm{N}$ and to surface slopes below $1^{\circ}$.

To assess trends of volume changes and hence of the mass balance of ice sheets, the continuity of the ice surface elevation measurement is of high importance (Pritchard et al., 2009; Flament and Rémy, 2012). The newest operating satellite-borne altimeter with ice applications is the ESA satellite CryoSat-2, which was launched in April 2010. As ENVISAT was lost in April 2012, CryoSat-2 is currently the only altimeter system providing surface elevation data of the Earth's polar regions. The main payload is an advanced radar altimeter, the Synthetic Aperture Interferometric Radar ALtimeter (SIRAL), which has been designed to detect changes in sea ice thickness as well as surface elevation changes of Earth's land and marine ice sheets (Wingham et al., 2006). CryoSat-2 provides altimetry data up to a latitude of $88.0^{\circ} \mathrm{S} / \mathrm{N}$, which is a significant improvement to previous satellite borne altimeters. The narrow across-track spacing of $2.5 \mathrm{~km}$ at $70^{\circ}$ and $4 \mathrm{~km}$ at $60^{\circ}$ deliver high data coverage at the margins of the ice sheet. This is an improvement compared to the coarse across-track spacing of $25 \mathrm{~km}$ at $70^{\circ}$ and $40 \mathrm{~km}$ at $60^{\circ}$ of the ICESat and ERS1/2/ENVISAT instruments.

In addition to the dense track spacing and the smaller data gap around the South Pole, CryoSat-2 also features the high accuracy in sloped terrain due to the newly developed SIRAL instrument. This capability is a significant improvement compared to the conventional altimeters on board ERS1/2/ENVISAT and enables continuous observations along the relatively steep and narrow margins of the ice sheets as well as on large glaciers and ice caps, where elevation change is most rapid.

In this study we present new DEMs and elevation change maps of both ice sheets, which are based on more than 3 years of continuous CryoSat-2 observations. In the following
Table 1. ICESat inter-campaign offset (LC) determined in Ewert et al. (2012a) updated for release 33 .

\begin{tabular}{lr|rr}
\hline LC & Bias (m) & LC & Bias (m) \\
\hline 1A & +0.068 & $3 \mathrm{~F}$ & +0.01 \\
2A & +0.009 & $3 \mathrm{G}$ & -0.04 \\
2A & +0.059 & $3 \mathrm{H}$ & -0.002 \\
2B & +0.038 & $3 \mathrm{I}$ & -0.015 \\
2C & -0.042 & $3 \mathrm{~J}$ & -0.047 \\
3A & +0.051 & $3 \mathrm{~K}$ & -0.06 \\
3B & +0.054 & $2 \mathrm{D}$ & -0.024 \\
3C & +0.028 & $2 \mathrm{E}$ & -0.033 \\
3D & -0.021 & $2 \mathrm{~F}$ & -0.029 \\
3E & -0.005 & & \\
\hline
\end{tabular}

section, we firstly describe the processing of the CryoSat-2 data in Sect. 2.2, and the procedure to generate DEMs from this data in Sect. 2.3. In Sect. 2.4 we explain the method used to derive elevation change ( $\mathrm{d} h / \mathrm{d} t)$ from CryoSat-2 and ICESat data. Validation and accuracy of the DEMs are described in Sect. 3.1. New findings, comparison and integrated volume estimates which are derived from the $\mathrm{d} h / \mathrm{d} t$ maps for both ice sheets are presented in Sect. 4. In Appendix A3 the derivation of the DEM uncertainty maps is described. To determine the elevation change uncertainty maps we propose two independent methods, which are explained in detail in Appendix A4.

\section{Data and methods}

\subsection{ICESat data and processing}

We use data acquired in the period from 2003 to 2009 from the Geo-science Laser Altimeter System (GLAS) on board NASA's Ice, Cloud, and land Elevation Satellite (ICESat) to validate the final CryoSat-2 DEMs as well as to derive $\mathrm{d} h / \mathrm{d} t$ for comparison. The ICESat data set GLA12 release 33 (Zwally et al., 2011) were used for this study. All surface elevations were referenced to WGS84 and corrected for saturation and an error in the range determination from transmit-pulse reference selection (centroid vs. Gaussian, GC) (Zwally, 2013; Borsa et al., 2013). A cloud filter was applied using internal data flags with thresholds given in Pritchard et al. (2009) and Kwok et al. (2007). The intercampaign offsets were determined for the release 33 data following Ewert et al. (2012a) and are listed in Table 1 (H. Ewert, personal communication, 2013).

\subsection{CryoSat-2 data and processing}

CryoSat-2's core instrument, the Ku-Band Synthetic Aperture Interferometric Radar Altimeter (SIRAL), samples the surface every $300 \mathrm{~m}$ along-track using three different measurement modes, LRM, SAR and SARIn (Wingham et al., 
2006). The low-resolution mode (LRM) is used over oceans and the flat interior of the ice sheets. LRM is a conventional pulse-limited radar altimeter that integrates the backscattered energy over the full beam width resulting in a footprint diameter of roughly $15 \mathrm{~km}$ considering an average altitude of $730 \mathrm{~km}$. The pulse-limited footprint is defined as the illuminated area on ground around the point of closest approach (POCA). It corresponds to the area illuminated by the leading edge of the transmitted pulse until the time the trailing edge first intersects the surface (Scagliola, 2013). The leading edge is used for the elevation detection. In the case of LRM, the pulse-limited footprint is dependent on the compressed pulse length ( $3.125 \mathrm{~ns}$ ) and is about $2.3 \mathrm{~km}$ in diameter. In the synthetic aperture (SAR) and synthetic aperture interferometric (SARIn) modes SIRAL samples the surface with a higher pulse repetition frequency $(18181 \mathrm{~Hz})$ than in LRM $(1970 \mathrm{~Hz})$. The Doppler history of the coherent radar data were then used in the SAR processing to increase the along-track resolution to approximately $305 \mathrm{~m}$. While the along-track footprint is decreased the across-track footprint stays the same.

In SARIn the second antenna mounted across the flight track direction is used to measure the phase difference of the incoming signal. This enables the POCA to be identified using interferometric processing (Wingham et al., 2004). SARIn measures the steep areas at the margins of the ice sheets and ice caps, whereas the SAR mode is used over sea ice to reveal ice free-board by distinguishing leads and ice flows.

The European Space Agency (ESA) provides calibrated processed CryoSat- 2 data as a level $1 \mathrm{~B}$ product, including the precise orbit of the satellite, the back-scattered radar waveforms, the tracker range and the coherence and phase difference for the SARIn mode. The product also contains additional information, such as geophysical and tidal corrections and quality flags. Before we generate the DEMs and the $\mathrm{d} h / \mathrm{d} t$ maps the CryoSat-2 data need to be processed. For this purpose we developed our own processor, which solves some of the remaining issues in the current ESA level 2 product (ESA, 2014).

We start our general processing using a waveform filter. Initially this identifies "bad waveforms" generated in rough or steep terrain when either the internal range tracker loses track or waveforms have no clear leading edge, e.g., due to high surface roughness. Then the range is determined using a threshold first maximum re-tracker (TFMRA, detailed description in Appendix A1) developed for this study to ensure the best possible re-tracking method for observing elevation changes. Davis (1997) suggested that for determining elevation changes, the most accurate approach is to use a threshold re-tracker focusing on the lower part of the leading edge and thus the surface scattering part. This ensures that spatial or temporal changes in the extinction coefficient of the snow, which effect mainly the volumetric component of the waveform do not influence the elevation measurement.
An example of the performance of the TFMRA is shown in Fig. 1, where a periodic pattern is observed at crossovers of ascending and descending tracks in East Antarctica. Results obtained with the ESA level 2 re-tracker, the NASA GSFC (Goddard Space Flight Center) (NASA, 2006), the offset center of gravity re-tracker (OCOG, using a threshold of 0.25 of the OCOG amplitude, Wingham et al., 1986) and the modified TFMRA (using a threshold of 0.25 of the first maxima) are shown in panels $\mathrm{a}-\mathrm{d}$, respectively. The static pattern is assumed to be caused by prominent wind fields at the East Antarctic Plateau (Armitage et al., 2013). However, the results of our study show that a correction for the static "Antarctic pattern" in $\mathrm{d} h / \mathrm{d} t$ estimates as applied in McMillan et al. (2014) can be avoided when using the TFMRA retracker.

The processing of LRM and SARIn is decoupled. For LRM/SAR the TFMRA re-tracking scheme is followed. Then the re-tracked range is passed to the next step. To SARIn waveforms we apply our interferometric processing scheme (details are described in Appendix A2), which implies TFMRA re-tracking and a relocation of the waveform position using the coherence and phase difference, both included in the level $1 \mathrm{~B}$ product. After re-tracking and/or interferometric processing the range is corrected for delays caused by the atmospheric refraction (ionosphere, wet and dry troposphere), solid Earth and pole tides. Data over the ice shelves around Antarctica are corrected for ocean loading and ocean tides using the model CATS2008a (Padman et al., 2002, 2008). It is important to note that the corrections for the inverse barometric effect were applied to all data points falling within the CATS2008a model extensions instead of using the surface type flags given in the level $1 \mathrm{~b}$ product. The CATS2008a model extensions are based on grounding lines derived from MODIS-based Mosaic of Antarctica (MOA) images (Haran et al., 2005) with updates from InSAR in a few places, notably the SE Ross Ice Shelf (L. Padman, personal communication, 2013). This step is necessary as the surface-type flags in the CryoSat-2 data product are imprecise. Applying the mask provided in the original data set, an unrealistic $\mathrm{d} h / \mathrm{d} t$ pattern is derived at the Ronne Ice Shelf and in the vicinity of the grounding line.

Finally, a correction is applied for the datation bias, since the LRM data are biased by $-4.7 \mathrm{~ms}$ (Scagliola and Fornari, 2013). The processed data, in the following section referred to as AWI (Alfred Wegener Institute) level 2 product, are then used as input for the DEM and $\mathrm{d} h / \mathrm{d} t$ processing.

\subsection{DEM generation}

For the DEM generation we used the AWI level 2 product acquired over a full 369-day-long cycle, starting January 2012.

We applied an iterative approach presented in the processing scheme in Fig. 2. LRM and SARIn processing are decoupled, as the slope is corrected in different ways for the two modes. When correcting for the slope each level $1 \mathrm{~b}$ echo 


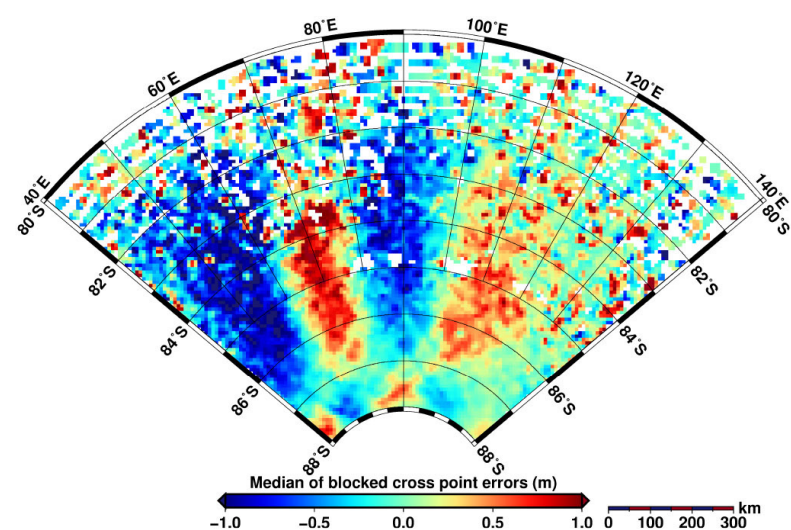

(a) L2

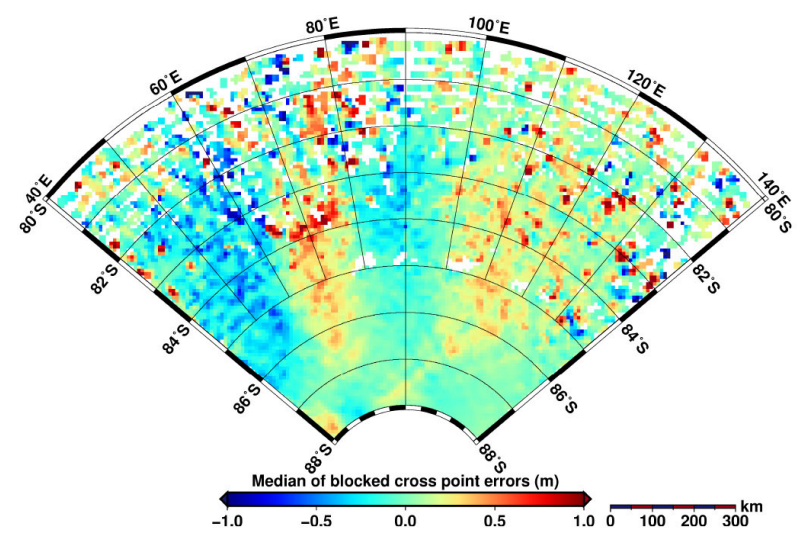

(c) OCOG

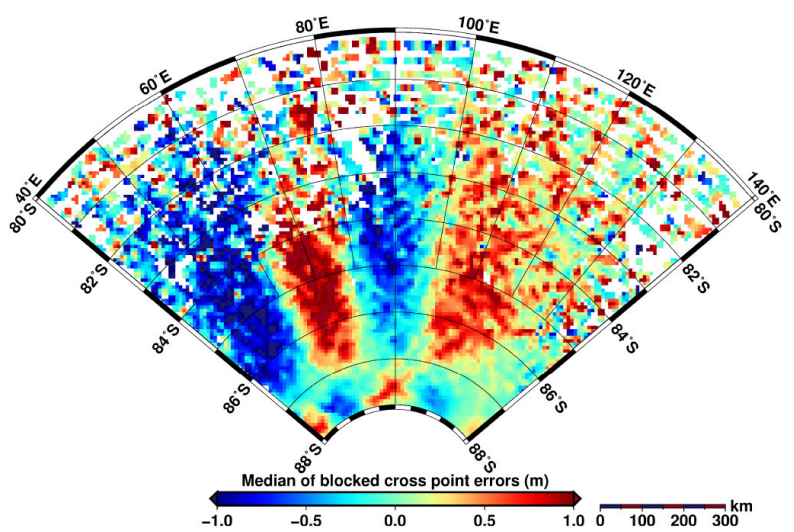

(b) GSFC

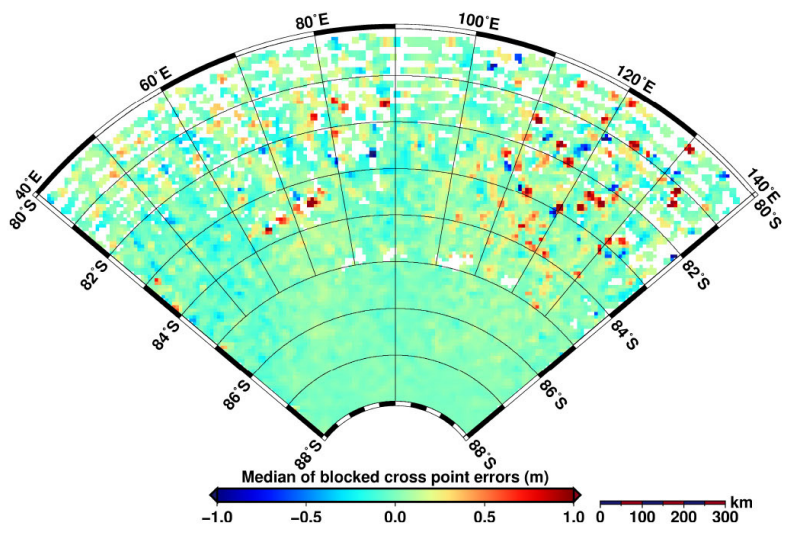

(d) TFMRA

Figure 1. Results of the LRM crossover analysis in East Antarctica using different re-trackers. The threshold first maximum re-tracker (TFMRA) gives the best results.

position along the orbit track is shifted up-slope towards POCA. Over-the-ocean POCA equals the sub-satellite point at nadir. The slope correction results in a relocation of the echo position as well as in a correction in range (Remy et al., 1989; Sandwell and Smith, 2014). Depending on the steepness of the slope the relocation can be in the order of several kilometers, whereas the range correction is usually of the order of some tens of meters (Brenner et al., 1983). For LRM we follow an iterative approach to correct for the surface slope. A first DEM with a pixel spacing of $1 \mathrm{~km}$ is generated from the input AWI level 2 data set using ordinary kriging interpolation and a search radius of $25 \mathrm{~km}$, (Isaaks and Srivastava, 1989; Deutsch and Journel, 1992). Then the slope correction is applied to each data point using the relocation method (Remy et al., 1989; Roemer et al., 2007). For each data point we determine the closest DEM pixel. As the initial DEM pixel spacing of $1 \mathrm{~km}$ is too coarse we interpolate a subset of $6 \mathrm{~km} \times 6 \mathrm{~km}$ of the initial DEM around the closest pixel to a $20 \mathrm{~m}$ pixel spacing. Then we determine the closest point in the re-sampled subset. After finishing the twostep relocation, a second DEM is generated with the slope- corrected data set replacing the first one. This iterative process is repeated four times, which leads to an improvement of the estimates. The method is converging as is presented in Fig. 3, where the residual differences $\frac{1}{N} \sum_{i=0}^{N}\left|h_{i}^{j+1}-h_{i}^{j}\right|$, $\frac{1}{N} \sum_{i=0}^{N}\left|\mathrm{DEM}_{i}^{j+1}-\mathrm{DEM}_{i}^{j}\right|$ and $\frac{1}{N} \sum_{i=0}^{N}\left|X Y_{i}^{j+1}-X Y_{i}^{j}\right|$ of the consecutive iterations are shown. $j$ is the iteration step, $h^{j}$ is the slope corrected elevation, $\mathrm{DEM}^{j}$ is the gridded elevation model and $X Y^{j}$ the relocated position after each iteration step. Due to this analysis we decided to stop the iteration after the fourth step since for all three variables only marginal improvements are expected beyond that.

In the SARIn processing the slope correction is directly derived from the phase difference at the re-tracked position. An iteration is not necessary, since after the interferometric processing the AWI L2 SARIn input data are slope corrected.

After the final iteration, both SARIn and LRM slope corrected data are merged and used for the DEM generation. We derived three different grids using different search radii defining the area around each grid cell from which data points are collected for the interpolation. To reduce the processing time, we limited the amount of data points used to 


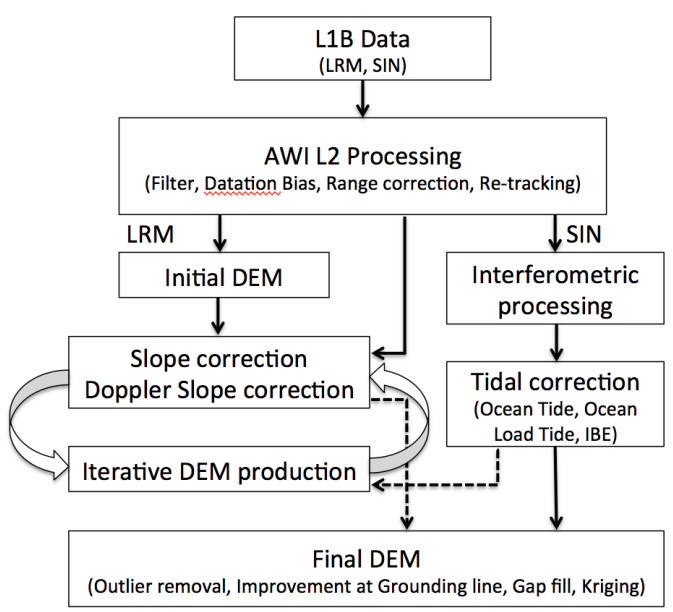

Figure 2. Diagram of the processing scheme used to derive the final DEM.

the nearest 80 points. The first grid has a pixel size of $1 \mathrm{~km}$ using a search radius of $6 \mathrm{~km}$; the second grid has a pixel size of $10 \mathrm{~km}$ using a search radius of $50 \mathrm{~km}$; and the third grid has a pixel size of $25 \mathrm{~km}$ using a $250 \mathrm{~km}$ search radius. Data gaps in the fine resolution $1 \mathrm{~km}$ grid occur where less than three data points are found in one of the eight sectors of each search circle. In a last processing step these gaps in the $1 \mathrm{~km}$ grid are filled by the re-sampled $10 \mathrm{~km}$ grid. This methodology prevents a unidirectional along-track weighting and guarantees a uniform weighting in the interpolation, since data coverage along-track is very high but can be sparse across-track. The across-track distance increases with lower latitude, and due to the slope correction large data gaps occur in areas of steep across-track slope, e.g., at the flanks of ice domes. In these locations retrieved POCA elevations are concentrated at the ridges. In mountainous or rough terrain or close to the grounding line, where the internal tracker loss occurred, less data coverage and hence large interpolation errors can be expected. To fill the data gap around the South Pole $\left(>88^{\circ} \mathrm{S}\right)$, we used the re-sampled $25 \mathrm{~km}$ grid. We did not consider older sparse cartographic data sets to fill the data gap around the South Pole, since they show errors of several hundreds of meters in the flat area between $88^{\circ} \mathrm{S}$ and $86^{\circ} \mathrm{S}$.

\subsection{Method for deriving elevation change}

We derived maps of elevation change, hereinafter referred to as $\mathrm{d} h / \mathrm{d} t$, using three full cycles of ESA level $1 \mathrm{~b}$ data acquired between January 2011 and January 2014 and for comparison from the full ICESat data set covering the period 2003 to 2009. As illustrated in Fig. 4, we processed the CryoSat-2 data according to Sect. 2.2 and applied the relocation slope correction using the new CryoSat-2 DEMs before estimating $\mathrm{d} h / \mathrm{d} t$. This prevents an underestimation of the basin-integrated volume change (Hurkmans et al., 2012a). ICESat data were processed according to Sect. 2.1. A slope

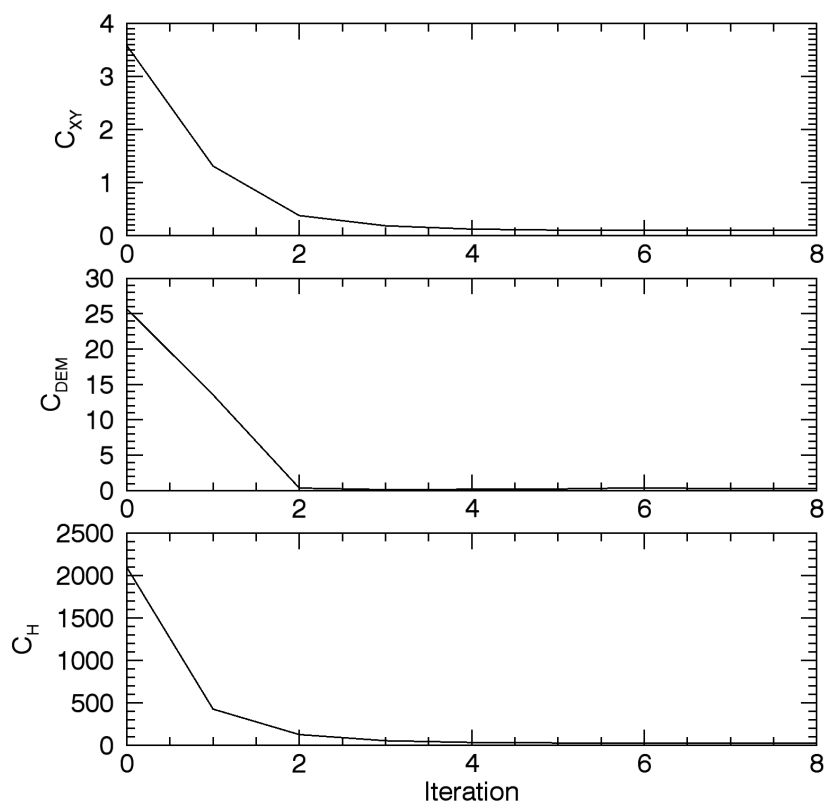

Figure 3. The convergence of the DEM iteration method is shown for Greenland as normalized sum of differences in $(\mathrm{m}) . C_{\mathrm{H}}=$ $\frac{1}{N} \sum_{i=0}^{N}\left|h_{i}^{j+1}-h_{i}^{j}\right|, C_{\text {DEM }}=\frac{1}{N} \sum_{i=0}^{N}\left|\mathrm{DEM}_{i}^{j+1}-\mathrm{DEM}_{i}^{j}\right|$, $C_{X Y}=\frac{1}{N} \sum_{i=0}^{N}\left|X Y_{i}^{j+1}-X Y_{i}^{j}\right| . j$ is the iteration step, $h^{j}$ is the slope corrected elevation, $\mathrm{DEM}^{j}$ is the elevation model and $X Y^{j}$ the relocated position after each iteration step.

correction is not necessary as the laser footprint is only $70 \mathrm{~m}$ in diameter. We limited the processed data sets to ice covered area using the GIMP ice mask for Greenland (Howat et al., 2014) and the rock outcrop polygon of the SCAR Antarctic Digital Database for Antarctica.

To determine the final elevation change maps a two-step procedure was carried out. In the first step a method which slightly differs from published ones (Pritchard et al., 2009; Smith et al., 2009; Sørensen et al., 2011; Ewert et al., 2012b) was applied. In previously published studies the authors used ICESat data, splitting ICESat reference tracks in $500 \mathrm{~m}$ wide segments along-track. For each segment or bin a least square model has been fitted to all measured elevations of the repeated tracks falling within the bin. The model estimates $\mathrm{d} h / \mathrm{d} t$, topography and a seasonal component in one step, whereas Ewert et al. (2012b) used a quadratic surface fit as an approximation for the topography the others assumed an inclined plane. Flament and Rémy (2012) applied a similar method to radar altimetry data of ENVISAT and extended the model with the additional waveform parameters backscatter, leading edge and trailing edge. The additional three parameters are obtained from the ICE2 re-tracking algorithm, (Legresy et al., 2005). The method presented here has its origin in the relocation slope correction and the interferometric processing. Since the elevation measurements are shifted towards the POCA a reference track is not suitable. Instead 


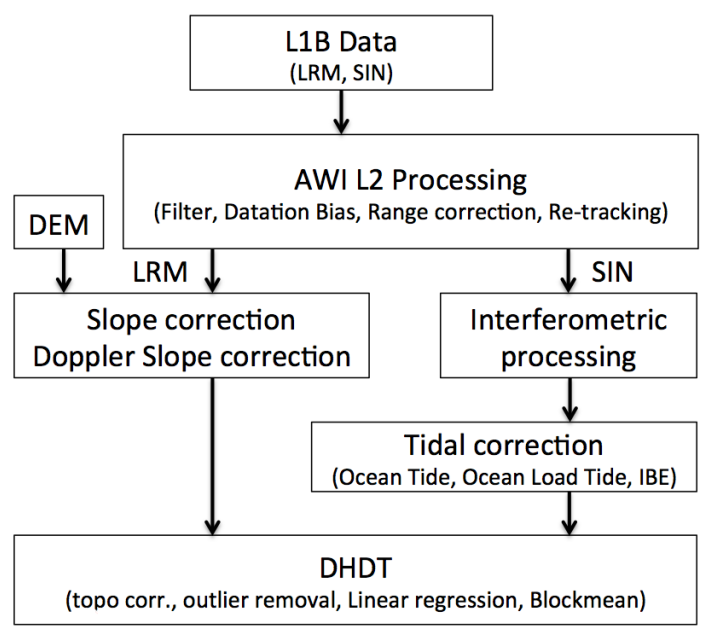

Figure 4. Sketch of the processing scheme used to derive the final $\mathrm{d} h / \mathrm{d} t$ map.

we generated empty grids with a $500 \mathrm{~m}$ pixel spacing covering the area of the ice sheets. For each pixel (indices $k, l$ ) all respective points $\left(N 1_{k, l}\right)$ located within a $500 \mathrm{~m}$ distance to that pixel were determined. Another difference of our approach is the usage of topographically corrected data instead of solving for the topography either as bi-linear or as biquadratic fit. The topographic correction considers the effect of slope and roughness on the $\mathrm{d} h / \mathrm{d} t$ estimates. As an example, two points separated by $1 \mathrm{~km}$ in a $0.1^{\circ}$ sloped area can be considered, which differ in height by $1.75 \mathrm{~m}$. Hence, it is necessary to apply a correction to every single elevation measurement before deriving $\mathrm{d} h / \mathrm{d} t$. The correction for each data point has been extracted from the new DEMs and then applied to the elevation. In a next step we rejected all topographic corrected elevations $\left(h_{\text {corr }_{i}}\right)$ larger than $\pm 100 \mathrm{~m}$ as outliers. For each pixel the elevation change $\left(\dot{h}_{k, l}\right)$ is estimated by a linear least square model fit to the $N 1_{k, l}$ topographic corrected points acquired at the time $t_{i}$ :

$h_{\text {corr }_{i}}=\alpha_{0}+\alpha_{1} t_{i}$,

where $N 1_{k, l}$ is the number of $h_{\text {corr }_{i}}$ and $\alpha_{1}=\dot{h}$. We restricted the method to bins where the covered time span of the contributing $h_{\text {corr }_{i}}$ measurements exceeded $1 / 2 \mathrm{yr}$ and $N 1_{k, l}>15$. On average the observed time span covered was $2.4 \pm 0.4$ years for CryoSat- 2 and $4.9 \pm 1.4$ years for ICESat, respectively. The average $N 1_{k, l}$ contributing to the fit within a bin for Greenland was $23 \pm 10$ for CryoSat-2 and $46 \pm 21$ for ICESat and for Antarctica $31 \pm 38$ for CryoSat-2 and $55 \pm 39$ for ICESat, respectively.

As the resulting grid contains data gaps between the tracks we derived the final interpolated elevation change grid $(\dot{h})$ with a pixel size of $1 \mathrm{~km}$ using the mean of all points not larger than $\pm 20 \mathrm{~m} \mathrm{yr}^{-1}$ falling within a $25 \mathrm{~km}$ distance to the corresponding pixel in a second step.
Finally, an uncertainty grid was generated using Gaussian error propagation described in Appendix A4. With this method an uncertainty estimate based on the elevation change measurement itself is derived.

\section{New digital elevations models of Greenland and Antarctica}

In this section, two new DEMs of Greenland and Antarctica and their uncertainty maps are presented. A total of 7.5 million and 61 million radar echoes for Greenland and Antarctica respectively have been used in the processing. Both final DEMs are regular grids with a pixel size of $1 \mathrm{~km} \times 1 \mathrm{~km}$. To prevent influences from inter-mission offsets, which are difficult to determine only CryoSat-2 data were used in the processing. Due to the short acquisition period of 1 year, influences of recent elevation changes are reduced, whereas previously published DEMs are compiled from data acquired over a long time period and different data sources. The most recent DEM of Antarctica, for example, is a composite of radar altimeter data of ERS1 acquired in 1994 and laser altimeter data acquired between 2003 and 2009 (Fretwell et al., 2013).

The new DEM of Antarctica presented in Fig. 5 covers an area of nearly $14 \mathrm{M} \mathrm{km}^{2}$, including ice shelves and the South Pole. In the corresponding slope map, derived from the gradient of the smoothed DEM ( $20 \mathrm{~km}$ kernel), the ice divides in East Antarctica are well represented (Fig. 6). Larger sub-glacial lakes such as Lake Vostok are also visible in the logarithmic color-scaled, continent-wide slope map. The derived surface slope is in good agreement with previous studies (Fretwell et al., 2013) and shows only minor differences in the low sloped areas and, as expected, higher differences of up to $0.3^{\circ}$ in steeper terrain. The slope azimuth is in very good agreement with the DEM of Fretwell et al. (2013), and therefore the ice divide positions do not differ significantly between both DEMs.

In Figs. 7 and 8 the Greenland DEM and its corresponding slope map are presented. The ice divides in central Greenland are clearly defined. Slopes increase towards the margins and exceed values of $2^{\circ}$ at the ice edge.

\subsection{DEM accuracy}

To retrieve the accuracy of the two CryoSat-2 DEMs for Antarctica and Greenland, we compared our DEMs with 2 million ICESat surface elevation points for Greenland and 22 million for Antarctica from the laser campaigns L3F, L3G and L3H, acquired in June 2006, November 2006 and March/April 2007 (Zwally et al., 2011). The elevation of the DEM at the laser footprint location was obtained by bi-linear interpolation. Differences are investigated qualitatively and as a function of surface slope, retrieved from both DEMs. To estimate the uncertainty induced by the ordinary kriging interpolation, we performed a cross-point analysis 


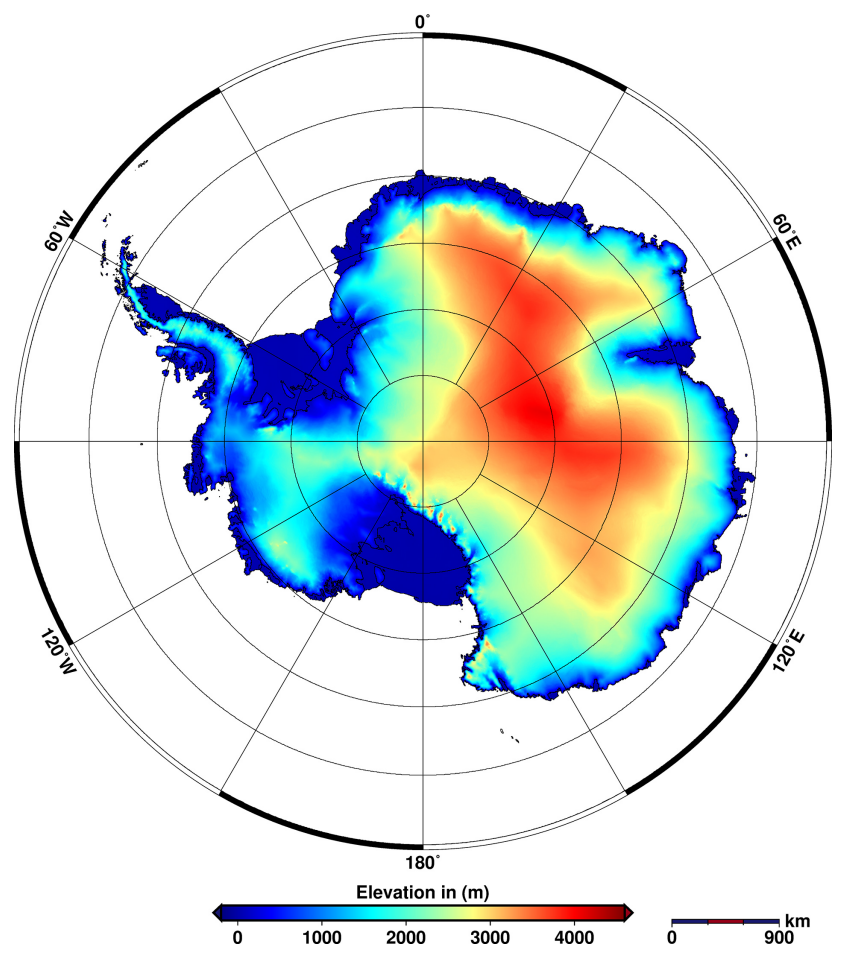

Figure 5. New elevation model of Antarctica derived from CryoSat-2.

of the input CryoSat-2 data set with the ICESat data. The accuracy of the ICESat data were determined from intramission crossover analysis of ICESat L3G campaign data over the entire Antarctic ice sheet. As is shown in Fig. 9, the accuracy of the DEM and the CryoSat-2 data themselves are slope-dependent, and thus degrading with steeper slopes. In contrast, the ICESat data show almost no slope dependency. The mean ICESat/ICESat cross over difference was found to be $0.01 \mathrm{~m}$ with a standard deviation of $0.65 \mathrm{~m}$ (46748 crossovers). Outliers deviating several meters are found in mountainous and crevassed areas and at locations where clouds could not be filtered out. Those findings are in agreement with reports of the GLAS (Geoscience Laser Altimeter System) engineering team and others (Bamber and Gomez-Dans, 2005; Shuman et al., 2006; Brenner et al., 2007; Shi et al., 2008). Based on these results, we assume that uncertainties in the ICESat data set are negligible and hence ICESat can be used as reference data set.

For the estimation of the accuracy of the Antarctic DEM we restricted our analysis to areas where the slope is less than $1.5^{\circ}$, which corresponds to $96 \%$ of the total surface area. Over 30, 82 and $96 \%$ of Antarctica has surface slopes of less than $0.1,0.5$, and $1.5^{\circ}$, respectively. In Fig. 9 the blue diamonds represent the median difference serving as uncertainty $(\varepsilon)$ and standard deviation $(\sigma)$ of CryoSat-2 data and ICESat at inter-mission crossovers plotted as a function of surface slope at intervals of $0.01^{\circ}$. In the same figure the red

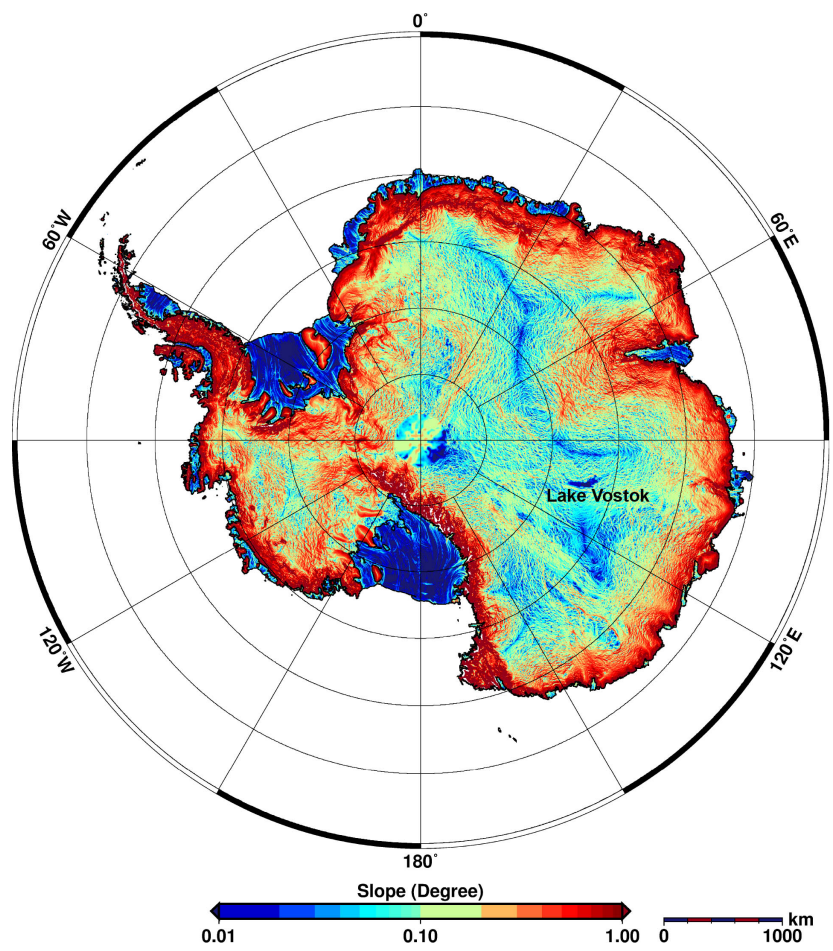

Figure 6. Surface slopes, estimated from the new elevation model of Antarctica.

diamonds represent the ICESat intra-mission crossover difference, indicating the high accuracy of the reference data. To avoid uncertainties caused by elevation changes occurred between 2007 and 2012, the reference ICESat data set were corrected using the ICESat elevation change map derived in Sect. 2.4, assuming a constant rate. It is evident that for areas with low slopes $\left(<0.1^{\circ}\right)$, which cover more than a third of the Antarctic ice sheet, the median difference of CryoSat-2 to ICESat is less than $0.2 \mathrm{~m} \pm 1.5 \mathrm{~m}$. Even for higher slopes of $1^{\circ}$ the uncertainty is below $3 \mathrm{~m} \pm 5 \mathrm{~m}$. The black diamonds in Fig. 9 indicate that the main component of the uncertainty of the DEM is caused by the ordinary kriging interpolation. $\varepsilon$ between the CryoSat-2 DEM and ICESat as well as $\sigma$ increase with increasing slope. However, $90 \%$ of the DEMs differ not more than $3.5 \mathrm{~m} \pm 15 \mathrm{~m}$. For the remaining $10 \%$, the uncertainty increases to $10 \mathrm{~m} \pm 30 \mathrm{~m}$. Large uncertainties occur in mountainous areas such as the Transantarctic Mountains, the Heimefrontjella in Dronning Maud Land, the catchment area of Amery Ice Shelf, Antarctic Peninsula, and at the rocky margins around Greenland. Errors below $1 \mathrm{~m}$ are found in the dry snow zone of Greenland, at ice domes and divides, ice shelves and also at Lake Vostok. A comparison with the latest elevation model of Antarctica (Fretwell et al., 2013) reveals differences of less than $10 \mathrm{~m}$ for $80 \%$ of the whole area. Larger offsets of up to $100 \mathrm{~m}$ occur in the mountainous areas, at the edges of ice caps and ice ridges close to the coast, and from the South Pole to $86^{\circ} \mathrm{S}$. The latter is caused by low-quality cartographic data south of $86^{\circ} \mathrm{S}$ used 


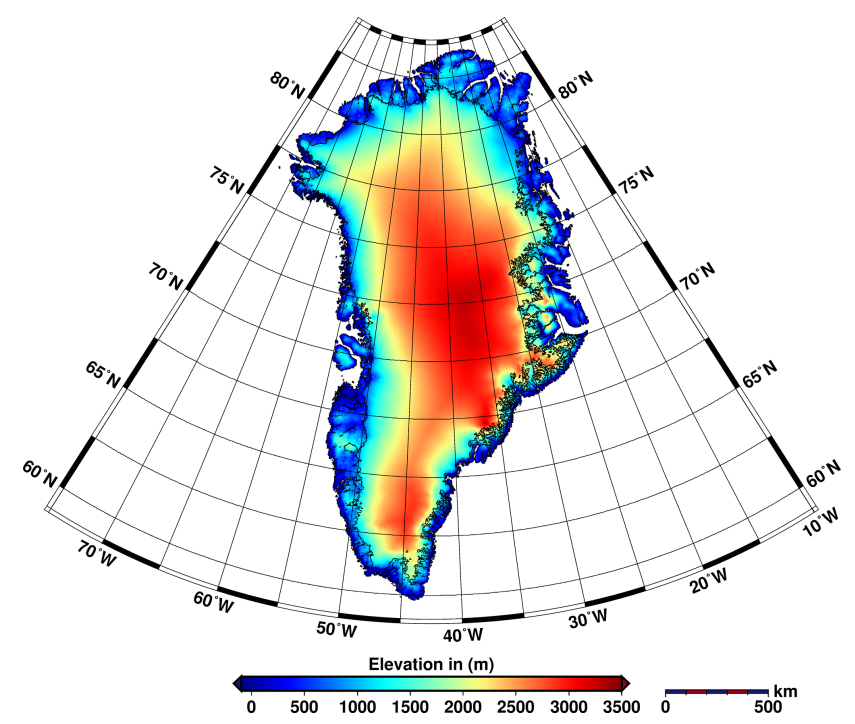

Figure 7. New elevation model of Greenland derived from CryoSat-2.

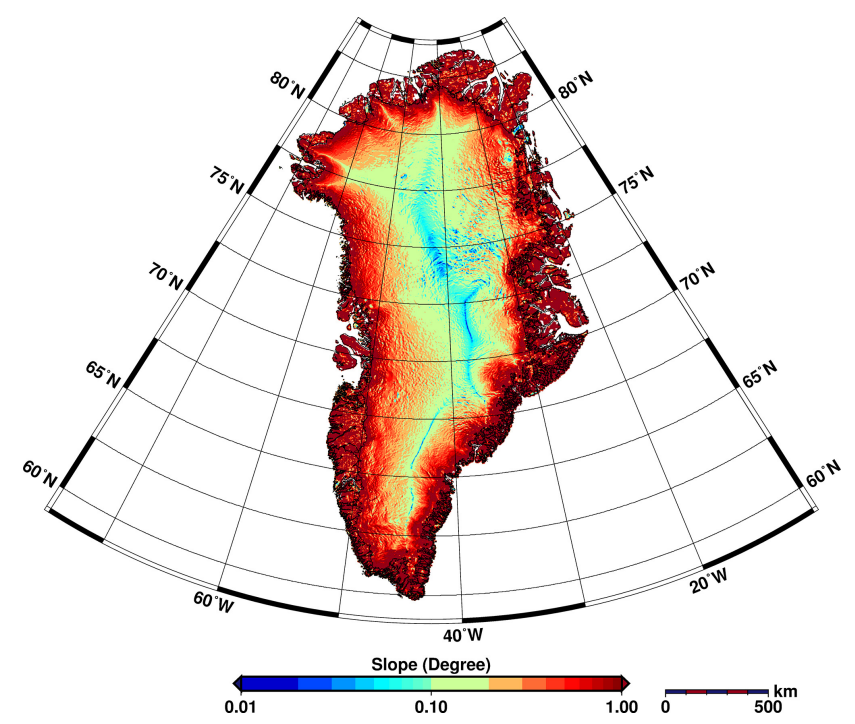

Figure 8. Surface slopes, estimated from the new elevation model of Greenland.

for the DEM in Fretwell et al. (2013), whereas CryoSat-2 deliver data up to $88^{\circ} \mathrm{S}$.

Due to the high data coverage of CryoSat-2, the Greenland DEM shows more detailed surface patterns than an older DEM which is based on ICESat data only (DiMarzio et al., 2007), especially in southern Greenland. However, the most recent high-resolution DEM of Greenland, produced within the Greenland Ice Mapping Project (GIMP) by Howat et al. (2014), gives more precise results than the CryoSat-2 DEM at the margins. Uncertainties derived by differencing ICESat data points and the CryoSat-2 DEM are less than $4 \mathrm{~m} \pm 25 \mathrm{~m}$ for areas of less than $1^{\circ}$. This corre-
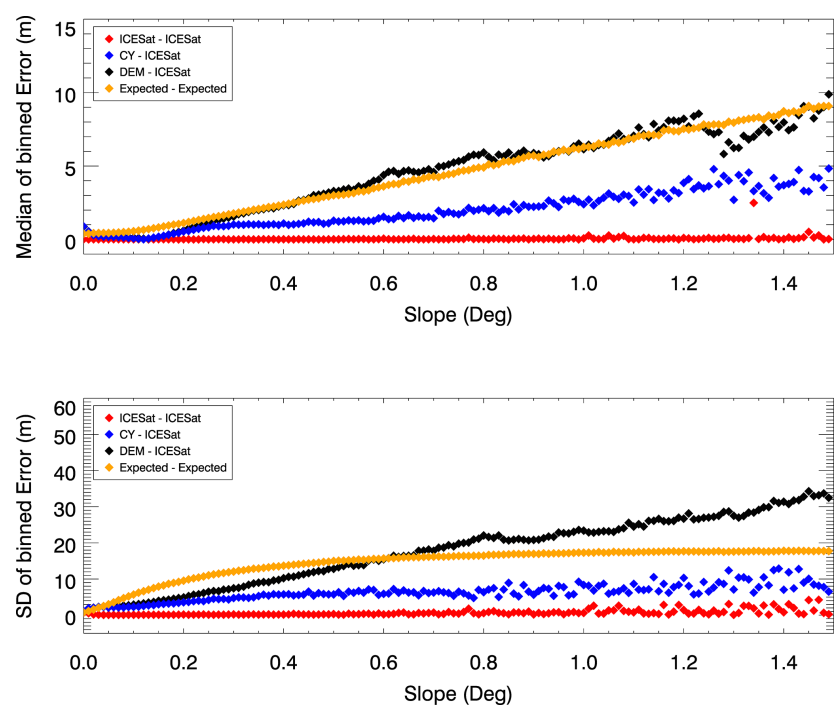

Figure 9. Binned elevation differences with respect to surface slope at a bin size of $0.01^{\circ}$ for Antarctica. The upper panel shows the median of the binned differences and the lower panel its standard deviation. Red diamonds represent ICESat cross over differences, blue diamonds Cryosat/ICESat crossover differences, black diamonds the differences between the DEM and ICESat and orange diamonds the expected DEM uncertainty based on the uncertainty grid.

sponds to approximately $75 \%$ of the area of Greenland. Especially the margins of Greenland, which are characterized by rocky outcrops, mountains and steep valleys, are not well represented and deviate from ICESat data points by more than $7 \mathrm{~m} \pm 40 \mathrm{~m}$. In contrast, the GIMP DEM deviates less than $2 \mathrm{~m} \pm 40 \mathrm{~m}$ from ICESat data points all over Greenland. A comparison of the CryoSat-2 DEM with the GIMP DEM revealed a mean difference of less than $1 \mathrm{~m} \pm 40 \mathrm{~m}$ for areas inside the GIMP ice mask.

Comparison with airborne laser scanner data (LSC) from the Alfred Wegener Institute and data of NASA's Airborne Topographic Mapper Instrument (ATM) (Krabill, 2014) and NASA's Land, Vegetation, and Ice Sensor (LVIS) (Blair and Hofton., 2010, updated 2012), acquired between 2010 and 2012 during the Operation Ice Bridge (OIB) missions, reveals reliable elevation of the new DEMs even in larger catchment areas at the margins. Results of the comparisons are presented in Table 2, where laser data from various kinds of surfaces are compared against the new CryoSat-2 DEMs and previously published DEMs for Greenland (Howat et al., 2014) and Antarctica (Fretwell et al., 2013). For all sites situated in low sloped areas, the CryoSat-2 DEMs are biased by less than $1 \mathrm{~m} . \sigma$ ranges from $0.2 \mathrm{~m}$ for Dome $\mathrm{C}$ and the North Eemian drilling site in north-western Greenland (NEEM) up to $45 \mathrm{~m}$ in the dry snow zone in Greenland (elevations above $2200 \mathrm{~m}$ ) and the area south of $85^{\circ} \mathrm{S}$. Even in areas of higher but gentle slope, e.g., Law Dome and Halvfaryggen in Dronning Maud Land, Antarctica, differences are less than $-0.1 \mathrm{~m} \pm 12 \mathrm{~m}$ and $0.3 \mathrm{~m} \pm 29 \mathrm{~m}$, respectively. The higher 


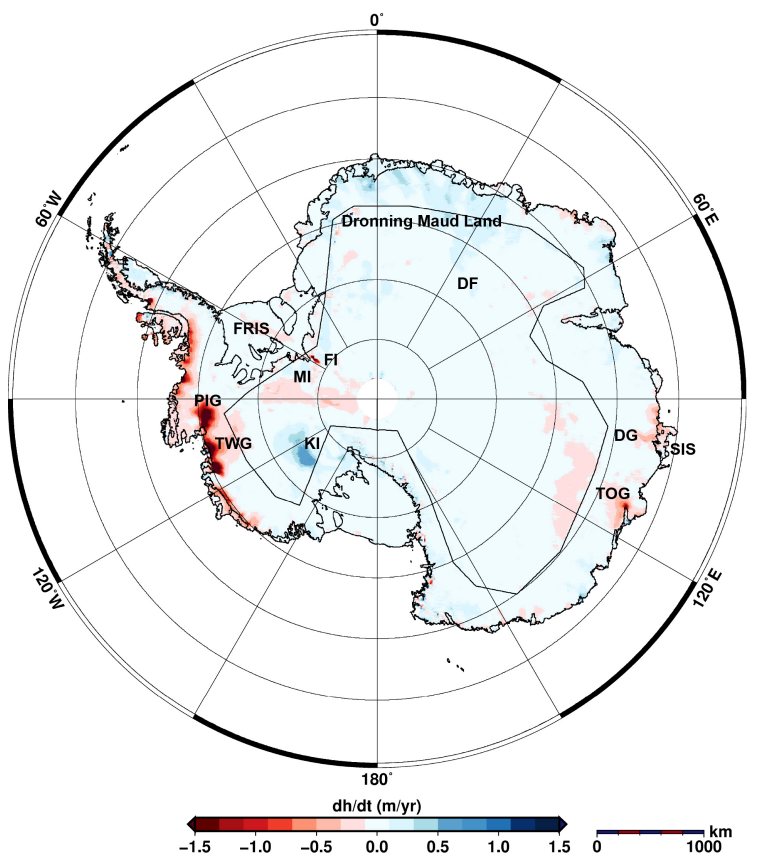

Figure 10. Map of elevation change of Antarctica between January 2011 and January 2014 derived from along-track processing of three full CryoSat- 2 cycles. The black polygon indicates the mode mask of CryoSat-2. Inside the polygon LRM and outside SARIn data were acquired. DF: Dome Fuji, PIG: Pine Island Glacier, TWG: Thwaites Glacier, TOG: Totten Glacier, FRIS: Filchner-Ronne Ice Shelf, FI: Foundation Ice Stream, MI: Moeller Ice Stream, DG: Denman Glacier, SIS: Shackelton Ice Shelf

$\sigma$ of Halvfaryggen can be explained by large interpolation errors due to data loss at the grounding line. Larger uncertainties of $4 \mathrm{~m} \pm 133 \mathrm{~m}$ are found in the rougher and steeper margins of Greenland (area below $2200 \mathrm{~m}$ ) and Antarctica (e.g., blue ice area close to the Schirmacher Oasis in Dronning Maud Land).

\section{Ice surface elevation change}

This study presents the first elevation change maps of Antarctica (Fig. 10) and Greenland (Fig. 11) derived from CryoSat-2 data acquired in the period January 2011 to January 2014. In total 14.3 million elevation measurements for Greenland and 200 million for Antarctica were used in Sect. 2.4 to derive the elevation change maps, which successfully reproduces the large-scale patterns of ice sheet change in both Antarctica and Greenland. Prominent in Antarctica is the strong dynamical thinning in the Amundsen Sea embayment in West Antarctica (Pine Island and Thwaites glaciers) of up to $10 \mathrm{~m} \mathrm{yr}^{-1}$ ). These results agree well with the dynamic mass loss observed by ICESat (Pritchard et al., 2009). Thinning is also observed at Totten Glacier in East Antarctica and at some large glaciers along the Antarctic Peninsula (Fig. 12). Dynamical thickening of the stagnated Kamb Ice

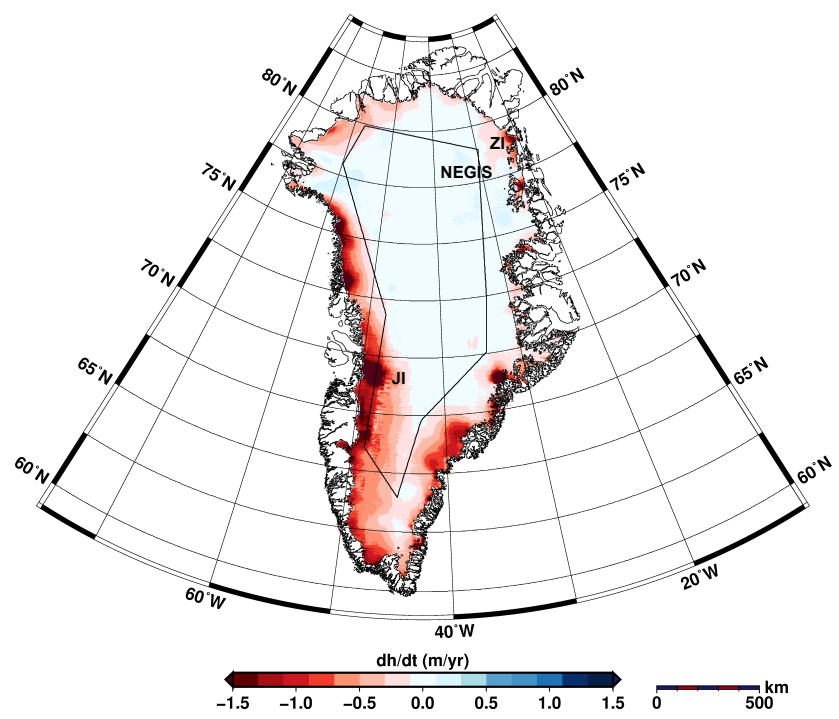

Figure 11. Map of elevation change of Greenland between January 2011 and January 2014 derived from along-track processing of three full CryoSat-2 cycles. The black polygon indicates the mode mask of CryoSat-2. Inside the polygon LRM and outside SARIn data were acquired. NEGIS: Northeast Greenland Ice Stream, JI: Jakobshavn Isbræ, ZI: Zacharias Isstrømen

Stream (Rose, 1979; Retzlaff and Bentley, 1993) is on the same order as presented previously (Pritchard et al., 2009). In Dronning Maud Land, East Antarctica an extended area was found where thickening of up to $1.0 \mathrm{~m} \mathrm{yr}^{-1}$ took place. The thickening decreases inland, but still reaches values of 0.1 to $0.2 \mathrm{~m}$ on the plateau. It represents an accumulation anomaly reported previously (Lenaerts et al., 2013; Boening et al., 2012). This case is anomalous in its magnitude and spatial extent and has an impact on the integrated volume change of Antarctica, as is shown below. In situ observations confirm the increase in accumulation rate. At the automatic weather station DK190 $\left(76.794^{\circ} \mathrm{S}, 31.9^{\circ} \mathrm{E} ; 3741 \mathrm{~m}\right.$ a.s.l. $)$ located $200 \mathrm{~km}$ southeast of Dome Fuji, accumulation exceeds the annual accumulation rate of $34.1 \mathrm{~kg} \mathrm{~m}^{-2} \mathrm{yr}^{-1}$ from previous years (Fujita et al., 2011) by $30 \%$ (S. Fujita and S. Kipfstuhl, personal communication, 2014). The remaining parts of the plateau do not show any significant elevation change.

Prominent in Greenland is the strong thinning of the entire western ice sheet, as well as the southeast and northwest ice sheet margins (Fig. 11). The dynamic thinning of Jakobshavn Isbræ in particular has penetrated deep into the ice sheet interior. Thinning of the Zacharias Isstrømen, an outlet glacier of the North East Greenland Ice Stream (NEGIS), show rates of $2.0 \mathrm{~m} \mathrm{yr}^{-1}$ at the glacier terminus. The observed thinning extends $100 \mathrm{~km}$ upstream of the NEGIS, where a few tens of $\mathrm{cm} \mathrm{yr}^{-1}$ have been reported (Thomas et al., 2009). Joughin et al. (2010b) showed an increase in speed and retreat of the terminus of Zacharias Isstrømen. Although this outlet glacier was previously reported to have a negative 
Table 2. Comparison of airborne laser altimetry data with the new CryoSat-2 DEMs and the GIMP DEM for Greenland (GRE) (Howat et al., 2014) and Bedmap2 DEM for Antarctica (ANT). (Fretwell et al., 2013). Laser data were acquired with the NASA Airborne Topographic Mapper instrument and/or the Land Vegetation and Ice Sensor (LVIS) during Operation Ice Bridge (OIB) missions by NASA. Laser scanner data (LSC) were acquired by the Alfred Wegener Institute (AWI) using a RIEGL LMS VQ-560 instrument.

\begin{tabular}{|c|c|c|c|c|c|}
\hline Region & Data & Date & $\begin{array}{r}\text { Difference to } \\
\text { CryoSat-2 DEM } \\
(\mathrm{m})\end{array}$ & $\begin{array}{r}\text { Difference to } \\
\text { GIMP/Bedmap2 } \\
(\mathrm{m})\end{array}$ & $N$ points \\
\hline $\operatorname{Raster}(30 \mathrm{~km} \times 50 \mathrm{~km})$ & LSC & & & & \\
\hline GRE (NEEM) & AWI & 2010 & $-0.3 \pm 0.22$ & $-0.08 \pm 0.92$ & 1883711 \\
\hline OIB all over & ATM & & & & \\
\hline GRE (above $2200 \mathrm{~m}$ ) & NASA & 2012 & $-0.01 \pm 45.0$ & $-0.25 \pm 27.0$ & 2088058 \\
\hline OIB all over & ATM & & & & \\
\hline GRE (below $2200 \mathrm{~m}$ ) & NASA & 2012 & $3.95 \pm 133.6$ & $1.97 \pm 21.80$ & 4519748 \\
\hline Four $70 \mathrm{~km}$ long tracks & LSC & & & & \\
\hline ANT (Halvfaryggen) & AWI & 2012 & $0.3 \pm 29.0$ & $1.1 \pm 44.0$ & 2087648 \\
\hline Star-like pattern $20 \mathrm{~km}$ & LSC & & & & \\
\hline ANT (Dome C) & AWI & 2012 & $-0.6 \pm 0.17$ & $-1.3 \pm 0.32$ & 347988 \\
\hline Raster $(20 \mathrm{~km} \times 40 \mathrm{~km})$ & LSC & & & & \\
\hline ANT (Law Dome) & AWI & 2012 & $-0.1 \pm 12.0$ & $2.8 \pm 6.0$ & 1322915 \\
\hline Raster $(20 \mathrm{~km} \times 30 \mathrm{~km})$ & LSC & & & & \\
\hline ANT (blue ice) & AWI & 2012 & $5.0 \pm 7.0$ & $1.6 \pm 20.0$ & 1791050 \\
\hline OIB ICESat validation & LVIS & & & & \\
\hline ANT (south of $85^{\circ} \mathrm{S}$ ) & NASA & 2009 & $0.6 \pm 39.4$ & $0.7 \pm 74.3$ & 1605224 \\
\hline OIB ICESat validation & LVIS & & & & \\
\hline ANT (south of $85^{\circ} \mathrm{S}$ ) & NASA & 2010 & $0.08 \pm 11.7$ & $1.95 \pm 33.5$ & 1561916 \\
\hline
\end{tabular}

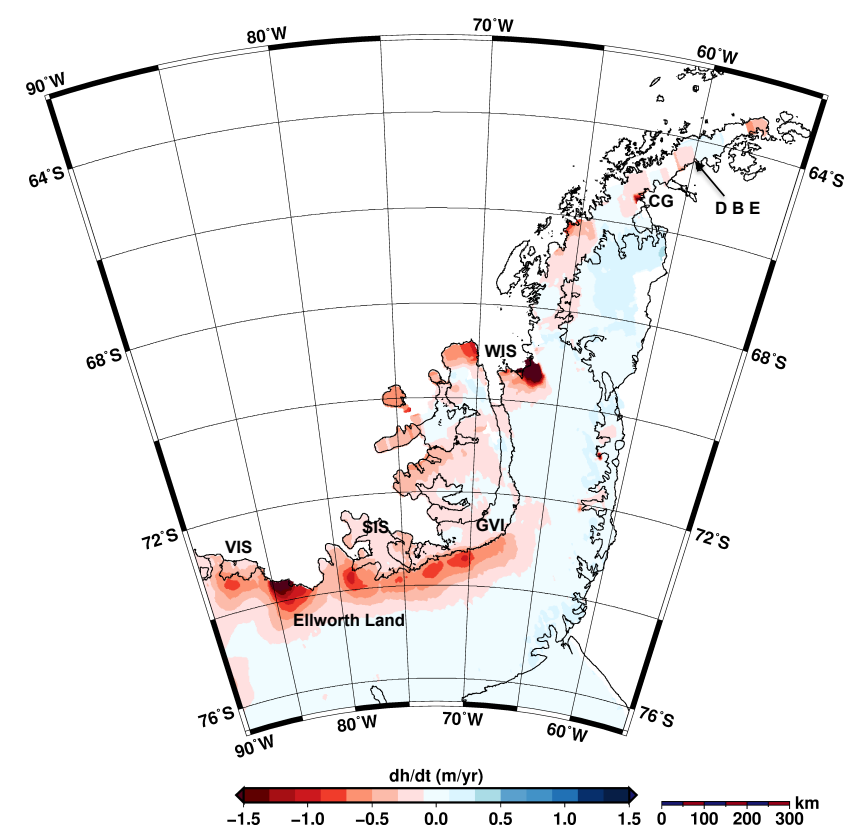

Figure 12. Elevation change occurring at the Antarctic Peninsula. VIS: Venable Ice Shelf, SIS: Stange Ice Shelf, GVI: George VI Ice Shelf, WIS: Wordie Ice Shelf, CG: Crane Glacier, DBE: Dinsmoor, Bombardier and Edgeworth Glacier. mass balance (Rignot and Kanagaratnam, 2006), this pattern of pronounced thinning is a new development (Khan et al., 2014). The interior of Greenland does not exhibit a significant change. Slight thickening is seen inland of the northwest coast of Greenland (up to $50^{\circ} \mathrm{W}$ ). Thickening reaches values of maximum $0.25 \mathrm{~m} \mathrm{yr}^{-1}$, also reported previously by Pritchard et al. (2009).

Figure 12 shows the elevation change occurring at the Antarctic Peninsula in greater detail. The pattern along the Antarctic Peninsula shows a few remarkable features: in the north Crane Glacier $\left(65.3^{\circ} \mathrm{S}, 62.25^{\circ} \mathrm{W}\right)$ shows a surface lowering of $2.3 \mathrm{ma}^{-1}$, which is consistent with the numbers reported previously by Scambos et al. (2011) for the period after the sub-glacial lake drainage event. Whereas the signal of surface lowering is much less pronounced at Bombardier, Dinsmoor and Edgeworth glaciers, tributaries of the former Larsen A Ice Shelf and the tributary of the former Wordie Ice Shelf are thinning at a rate of $3.5 \mathrm{ma}^{-1}$ some 20 years after the collapse of the ice shelf.

While Venable Ice Shelf is still thinning at a rate as presented by Pritchard et al. (2012), the adjacent coast of Ellsworth Land $\left(73.75^{\circ} \mathrm{S}, 84.0^{\circ} \mathrm{W}\right)$ exhibits highly increased surface lowering reaching $2.2 \mathrm{ma}^{-1}$. Furthermore the western flank of the southern Antarctic Peninsula in the vicinity of Stange and George VI ice shelves show a pronounced surface lowering. This is most likely due to variations in the surface accumulation rate as a dynamic thinning is unlikely to occur. This is supported by Thomas et al. (2008) who showed high 
Table 3. Elevation change $\left(\mathrm{m} \mathrm{yr}^{-1}\right)$ at GPS points from Scott et al. (2009) at Pine Island Glacier.

\begin{tabular}{lrrr}
\hline & PC55 & PC111 & PC171 \\
\hline 2003-2007 & $-1.9 \pm 0.4$ & $-1.0 \pm 0.4$ & $-0.6 \pm 0.4$ \\
ICESat (Scott et al., 2009) & $-3.5 \pm 0.65$ & $-2.0 \pm 0.4$ & $-1.2 \pm 0.2$ \\
2006/2007 & & & \\
GPS (Scott et al., 2009) & $-3.3 \pm 0.5$ & $-2.3 \pm 0.3$ & $-1.6 \pm 0.2$ \\
2003-2008 & & & \\
2003-2009 & $-2.4 \pm 0.1$ & $-1.2 \pm 0.1$ & $-0.8 \pm 0.1$ \\
ICESat (this study) & & & \\
2011-2014 & $-1.8 \pm 0.1$ & $-1.6 \pm 0.1$ & $-1.4 \pm 0.1$ \\
CryoSat-2 (this study) & & & \\
\hline
\end{tabular}

surface accumulation rates and inter-annual variations in a range consistent with our results.

\subsection{Areas of large elevation changes}

In the following two prominent regions with large surface elevation change are discussed: Jakobshavn Isbræ and Pine Island Glacier (PIG). Figure 13 reveals that areas with detected thinning correspond with the location of the PIG tributaries. Thinning of the tributaries reaches far upstream and exceeds values of $1 \mathrm{~m} \mathrm{yr}^{-1}$. Areas with flow velocities as low as $100 \mathrm{~m} \mathrm{yr}^{-1}$ are affected. The thinning rates are in agreement with other studies reporting accelerated thinning of the order of 0.1 to $0.2 \mathrm{ma}^{-2}$, (e.g., Scott et al., 2009; Wingham et al., 2009; Flament and Rémy, 2012; Smith et al., 2012). Figure 13 displays the Pine Island Glacier catchment basin, a subset of the CryoSat- $2 \mathrm{~d} h / \mathrm{d} t$ grid, overlain by the CryoSat-2 measurements as dark-gray dots, ICESat as black dots and the three GPS sites (Scott et al., 2009) as yellow hexagons. Table 3 presents the comparison to the findings of Scott et al. (2009) at the in situ GPS sites. The two upstream GPS sites (PC111 and PC171) show higher elevation change rates for CryoSat-2 data than for ICESat data. At site PC55, which is located downstream, the CryoSat-2 estimates equal those of ICESat. Observed differences might reflect a change of the dynamics of PIG, or may also be caused by interpolation artifacts since the closest ICESat data point is approximately $10 \mathrm{~km}$ apart from the PC55 site, whereas it is much closer for PC111 and PC171 $(2 \mathrm{~km})$. At all sites the GPS measured elevation change in 2007 is almost twice that of the ICESat observed change for the same period. This offset might be caused by the spatial averaging (mean filtering) applied in the processing, leading to an underestimation of local maxima. We therefore assume that the CryoSat-2 results give more conservative estimates of recent elevation change.

The second example is Jakobshavn Isbræ (Fig. 14), which has accelerated to velocities of $\sim 16 \mathrm{~km} \mathrm{yr}^{-1}$ (Joughin et al., $2010 \mathrm{~b}$ ) after its floating tongue disintegrated in 2003. Thinning was previously reported by Thomas et al. (2003) and Csatho et al. (2008). Thinning rates observed in 2011-2012 exceeded $4 \mathrm{~m} \mathrm{yr}^{-1}$. The thinning is most pronounced in the lower part of both tributaries, but extends $250 \mathrm{~km}$ upstream. This value is much lower than the $17 \mathrm{~m} \mathrm{yr}^{-1}$ at the glacier terminus reported by Hurkmans et al. (2012b) and a rather conservative estimate that is influenced by the spatial averaging. As shown in Fig. 14 data gaps occur in the vicinity of the grounding line as well as in the higher elevated parts of the basin. Here, CryoSat-2 lost track and/or the LRM waveforms were degraded due to high surface slopes of more than $0.6^{\circ}$ and high surface roughness.

\subsection{Comparison with elevation change estimates from ICESat}

In this section we compare recent elevation change derived from CryoSat-2 data with $\mathrm{d} h / \mathrm{d} t$ derived from ICESat data acquired from 2003 to 2009 for both ice sheets. For both altimeters the same along-track technique explained in Sect. 2.4 was applied. Comparisons of our ICESat results with previous studies carried out by Pritchard et al. (2009); Sørensen et al. (2011); Zwally et al. (2011); Ewert et al. (2012b); Groh et al. (2014) show the same large scale patterns. We can also confirm the estimates of Scott et al. (2009), which give additional confidence in the robustness of the algorithm used. However, the comparison of our integrated volume change rates with those derived in the Ice sheet Mass Balance Inter-comparison Exercise (IMBIE) study of Shepherd et al. (2012) gave higher numbers for Greenland and the Antarctic Peninsula but smaller numbers for East and West Antarctica. In the IMBIE study four different groups contributed their volume estimates derived from ICESat data. A large spread in the volume-rate estimates, particularly for West Antarctica (WA), was observed in this study. For WA the values range from -7 to $-51 \mathrm{~km} \mathrm{yr}^{-1}$. One possible explanation could be that the different groups used different ICESat data releases, data-editing methods and inter campaign offsets. We found that the G-C offset correction, which was applied in this study but not in others, had only a little effect $\left(2 \mathrm{~km} \mathrm{yr}^{-1}\right.$ for Greenland and Antarctica). Therefore we assume that most of the observed differences are caused 


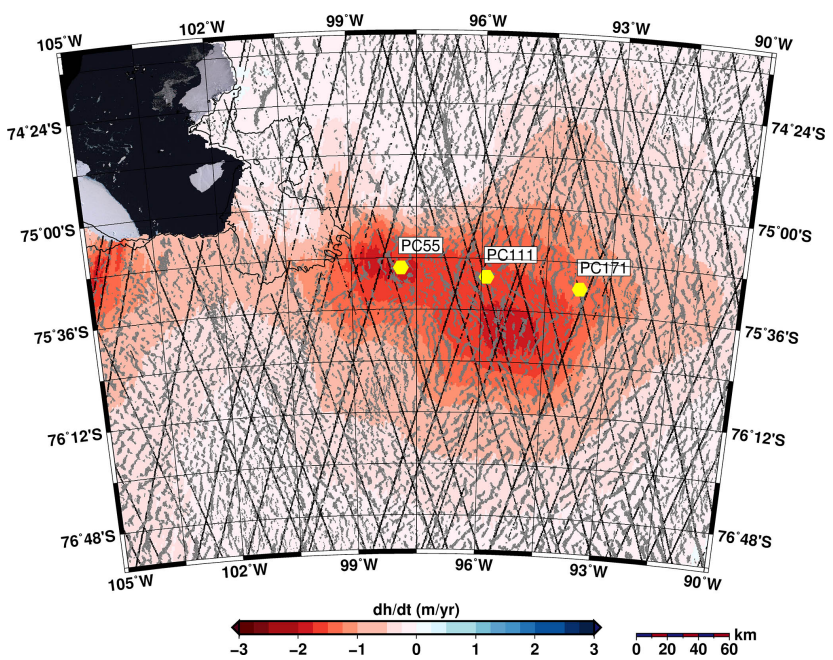

Figure 13. Elevation change occurring at the Pine Island Glacier in West Antarctica. Data coverage of $\mathrm{d} h / \mathrm{d} t$ measurements are shown for CryoSat-2 (gray) and ICESat (black). The yellow hexagons represent the GPS sites in Scott et al. (2009)

by the differences between the interpolation techniques employed by the groups. The same conclusions are derived in the IMBIE study (Shepherd et al., 2012).

A subsequent comparison of $\mathrm{d} h / \mathrm{d} t$ derived from CryoSat-2 and ICESat exhibits the accumulation anomaly described earlier, as well as the continued and increased thinning of ice in West Greenland and the Amundsen Sea Embayment. This is shown in Figs. 15 and 16 where the difference of both $\mathrm{dh} / \mathrm{dt}$ maps is presented. An increased thinning of the west coast of the Antarctic Peninsula as well as of Denman Glacier feeding the Shackleton Ice Shelf in East Antarctica is observed. The Denman Glacier thinning mirrors the findings of Flament and Rémy (2012) who observed $-0.4 \mathrm{~m} \mathrm{yr}^{-1}$ and is in contrast with estimates of Rignot (2002) observing a slight mass gain of $2.3 \mathrm{~km}^{3}$ ice $\mathrm{yr}^{-1}$. In contrast to Joughin and Bamber (2005) who observed slight thickening of the ice stream catchments feeding the Filchner-Ronne Ice Shelf we observe a slight thinning of the catchments of Institute and Moeller Ice Streams. High negative elevation changes of up to $-2 \mathrm{~m} \mathrm{yr}^{-1}$ are observed in the lower part of the Foundation Ice Stream where Joughin and Bamber (2005) estimated a mass balance of $11.2 \mathrm{Gt} \mathrm{yr}^{-1}$. For the Foundation Ice Stream, high steady state sub glacial melt rates of $9 \mathrm{~m} \mathrm{yr}^{-1}$ have been reported, exceeding melt rates of the surrounding ice streams (Lambrecht et al., 1999).

\section{Conclusions}

We derived DEMs for Antarctica and Greenland from one full cycle (369 days) of CryoSat-2 data starting January 2012. We estimated the uncertainty to be less than $3.5 \mathrm{~m} \pm 15 \mathrm{~m}$ for Antarctica and $5 \mathrm{~m} \pm 65 \mathrm{~m}$ for Greenland in approxi-

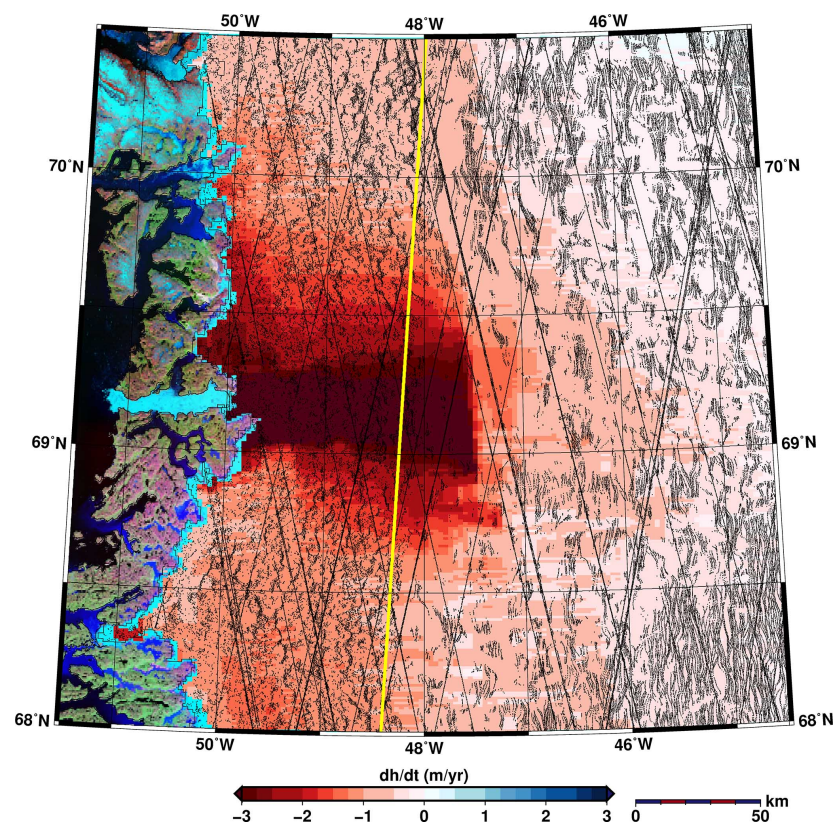

Figure 14. Jakobshavn Isbræ is experiencing massive thinning of more than $4 \mathrm{~m} \mathrm{yr}^{-1}$. The thinning extends more than $250 \mathrm{~km}$ inland. Data coverage of $\mathrm{d} h / \mathrm{d} t$ measurements are shown for CryoSat-2 (gray) and ICESat (black). The yellow line running from north to south indicates the mode mask of CryoSat-2. To the west of this line SARIn and to the east LRM data were acquired. Unfortunately, CryoSat-2 show data loss in LRM zone of the catchment area of the glacier due to the high surface roughness and surface slopes.

mately $90 \%$ of the area of the ice sheets. The deviations from previous DEMs are small except in the area between $86^{\circ} \mathrm{S}$ and $88^{\circ} \mathrm{S}$, where our data set is significantly improved by the further southward reaching coverage of the CryoSat-2 data. For the CryoSat-2 data processing we developed the new TFMRA re-tracker. With cross-over analysis over East Antarctica and comparisons to three other re-trackers we demonstrated the better performance of the TFMRA. An iterative approach for the slope correction, as well as the new interferometric processing algorithm for the SARIn data were used for the DEM generation. The convergence of the iterative approach has been demonstrated.

Based on three full cycles of CryoSat- 2 the combined volume loss of both ice sheets for the covered time period from January 2011 to January 2014 is estimated to be $507 \pm$ $107 \mathrm{~km}^{3} \mathrm{yr}^{-1}$. In Table 4 the volume rates are listed, which indicate that Greenland is contributing $-375 \pm 24 \mathrm{~km}^{3} \mathrm{yr}^{-1}$, which is nearly $75 \%$ of the total volume loss. For Greenland we observe a factor of 2.5 higher volume loss than for the time period between 2003 and 2009 revealed from ICESat using the same methodology. Our ICESat estimates are different than the IMBIE study (Shepherd et al., 2012). We assume this is caused by the differences between the interpolation techniques used in our study compared to those employed by the four different groups in the IMBIE study, 
Table 4. Volume rate estimates of ICESat and CryoSat-2 derived in this study compared with ICESat from IMBIE (Shepherd et al., 2012).

\begin{tabular}{lrrrr}
\hline Region & Area & $\begin{array}{r}\text { IMBIE } \\
2003-2008\end{array}$ & $\begin{array}{r}\text { ICESat } \\
2003-2009 \\
\left(\mathrm{Mio} \mathrm{km}^{2}\right)\end{array}$ & $\begin{array}{r}\text { CryoSat } \\
2011-2014 \\
\mathrm{~d} V / \mathrm{d} t\left(\mathrm{~km}^{3} \mathrm{yr}^{-1}\right)\end{array}$ \\
\hline GrIS & 1.68 & $-189 \pm 20$ & $-146 \pm 13$ & $-375 \pm 24$ \\
APIS & 0.22 & $-28 \pm 11$ & $+14 \pm 9$ & $-35 \pm 9$ \\
EAIS & 9.74 & $+78 \pm 19$ & $-23 \pm 26$ & $+59 \pm 63$ \\
WAIS & 1.74 & $-25 \pm 7$ & $-51 \pm 9$ & $-152 \pm 11$ \\
AIS & 11.71 & $+25 \pm 12$ & $-60 \pm 44$ & $-128 \pm 83$ \\
\hline GrIS + AIS & 13.39 & $-164 \pm 32$ & $-207 \pm 57$ & $-503 \pm 107$ \\
\hline
\end{tabular}

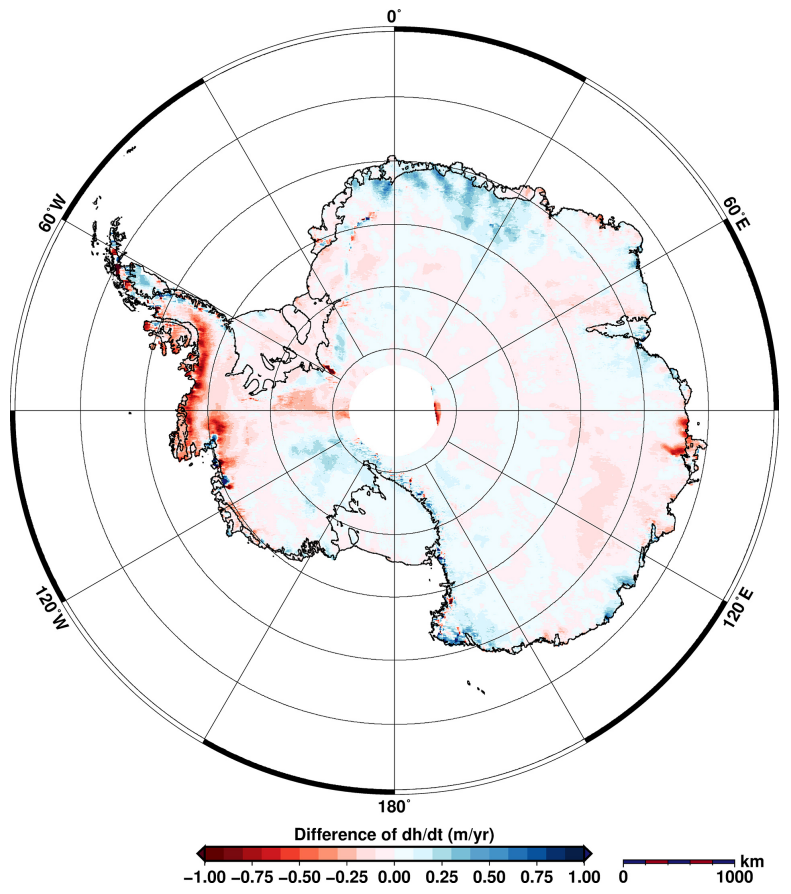

Figure 15. Difference of $\mathrm{d} h / \mathrm{d} t$ between the period 2011 to 2014 and the period 2003 to 2009

which show also large differences. However, our observed increase of volume loss mirrors the findings of Tedesco et al. (2013), who reported a mass loss record in 2011/2012 of $-575 \pm 95 \mathrm{Gt} \mathrm{yr}^{-1}$. In Antarctica the estimated volume loss is $-128 \pm 83 \mathrm{~km}^{3} \mathrm{yr}^{-1}$. Similar to the Greenland margins, West Antarctica is experiencing an increase in volume loss as observed in previous studies (Rignot et al., 2011; McMillan et al., 2014). Compared to the period 2003 to 2009, the loss increased by a factor of 3 from $-51 \pm 9$ to $-152 \pm$ $11 \mathrm{~km}^{3} \mathrm{yr}^{-1}$. Furthermore, the results clearly demonstrate that accumulation events on a large spatial and short temporal scale, as observed in Dronning Maud Land, are partly compensating for the increasing volume loss.

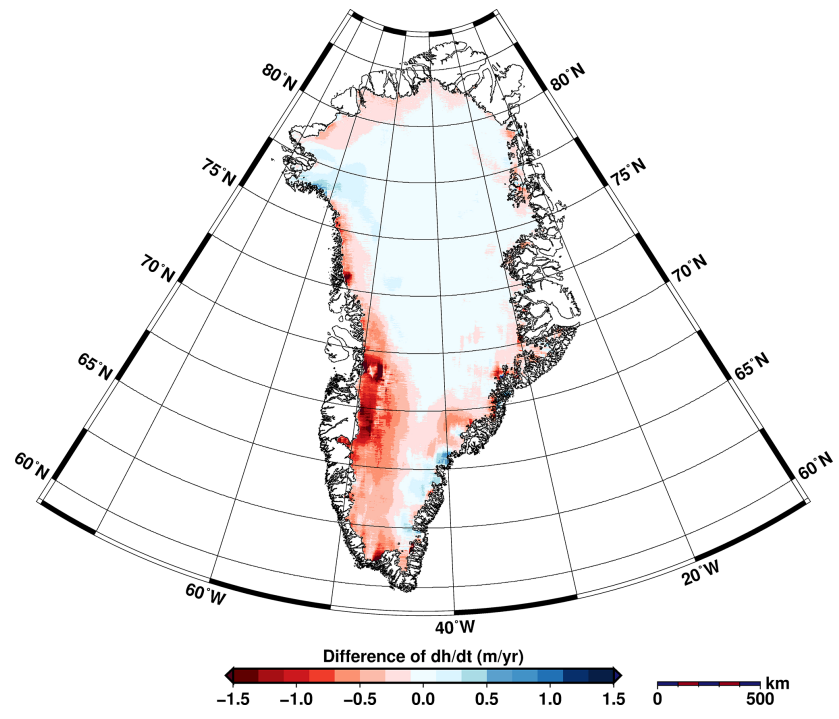

Figure 16. Difference of $\mathrm{d} h / \mathrm{d} t$ between the period 2011 to 2014 and the period 2003 to 2009

This sheds new light on the temporal evolution of volume change and consequently mass change of the ice sheets and raises the question on which time-scale sea level change responds to yearly mass imbalances of the ice sheets, as well as how regional sea level observations will capture this. To answer those questions it is important to continue the measurement of elevation change using advanced technologies such as CryoSat-2 and to extend time series of elevation change dating back to the early 1990s. Furthermore, it is imperative to extend the operational CryoSat-2 data acquisition as long as possible as it is currently the only remaining altimeter system observing polar regions since the loss of ICESat in 2009 and ENVISAT in 2012. This will bridge the gap until the launch of ICESat-2 expected for 2018.

The complete set of grids are available in geotiff format from the lead author (V. Helm) and will be provided on the data server PANGAEA (http://www.pangaea.de). Users will be notified of new releases as they become available. 


\section{Appendix A}

\section{A1 TFMRA re-tracker}

In summary the simple and robust TFMRA re-tracker approach consists of the following steps.

- Normalization of waveform to its maximum.

- Calculate the thermal noise using the first $n$ range bins:

$$
P_{\mathrm{N}}=\frac{1}{n} \sum_{i=0}^{n} P_{i}, \text { with } n=6 .
$$

- Flag waveforms with $P_{\mathrm{N}}>T_{\mathrm{N}}$ with the a noise threshold of $T_{\mathrm{N}}=0.15$ as bad data, which contain no valid elevation.

- Over-sample waveform by a factor of 10 using linear interpolation.

- Calculate the smoothed waveform $(P)$ with a boxcar average of width 15 .

- Calculate first derivative $d P$ using a 3-point Lagrangian interpolation.

- Determine the first local maxima $\left(P_{\max 1}\right)$ using $d P$ and the criteria.

$P>P_{\mathrm{N}}+T_{\mathrm{N}}$

- Determine the location $\hat{n}$ of the first gate exceeding the threshold level TL at the leading edge of the first local maxima, where $P>P_{\max 1} \times \mathrm{TL}+P_{\mathrm{N}}$. For TL we used 0.25 for LRM and 0.4 for SAR/SARIn.

- Determine the leading edge position $n_{\text {ret }}$ by interpolation between adjacent oversampled bins to the threshold crossing using Eq. (4) in Davis (1997):

$$
n_{\text {ret }}=(\hat{n}-1)+\frac{\mathrm{TL}-P_{\hat{n}-1}}{P_{\hat{n}}-P_{\hat{n}-1}}
$$

\section{A2 Interferometric processing}

To each waveform $(W)$, the coherence $(C)$ and the phase difference, $(\Delta \phi)$ is given in the ESA level 1B product, each composed of 512 samples. The range resolution is approx. $0.23 \mathrm{~m}$, resulting in a range window $(R)$ which is composed of 512 samples spanning approx. $118 \mathrm{~m}$. In detail the interferometric processing is as follows.

- Smooth $\Delta \phi$ in the complex domain.

- Re-track waveform $W$ using the OCOG re-tracker, which is very fast and robust. We take the center of gravity as the re-tracked position $(\hat{n})$, which is situated more towards the maximum of $W$ instead at the beginning of the leading edge.
- Starting from $\hat{n}$ we search the sample where $C>0.7$ $\longrightarrow \hat{n_{c}}$. This and the step before avoids influences of phase noise during the phase unwrapping.

- Unwrap smoothed $\Delta \phi$ in two directions starting from $\hat{n_{c}}$.

- From the unwrapped phase the surface slope is calculated following Jensen (1999); Galin et al. (2013)

$\alpha=\eta\left[F_{c} \theta-\gamma\right]=\eta\left[F_{c} \sin ^{-1}\left(\frac{\Delta \phi \lambda}{2 \pi B}\right)-\gamma\right]$.

$F_{c}=1 / 0.973$ is a scaling factor to be applied to the angle of arrival $\theta$, determined by Galin et al. (2013) using CryoSat-2 data acquisitions over ocean during a sequence of satellite roll maneuver. The geometric factor $\eta$ accounts for the earth curvature and is given by the expression $\eta=1+(H / R)$, where $H$ is the orbit altitude and $R$ the Earth's local ellipsoidal radius. $\gamma$ is the roll angle, $B=1.1676 \mathrm{~m}$ is the antenna Baseline and $\lambda=0.0221 \mathrm{~m}$ is the wavelength, (Bouzinac, 2014). Galin et al. (2013) observed a mispointing of the antenna in pitch and roll directions as well as a small temperature dependent bending of the baseline. Both mispointings are of the order of $0.1^{\circ}$ and a correction for the roll mispointing has been applied as external phase correction in the level 1B product (Scagliola and Fornari, 2013). The bending is variable in time and varies along the orbit of some $100 \mu \mathrm{rad}$. In contrast to the mispointing in roll direction the pitch mispointing is not critical to the accuracy of the derived elevation.

- Define the subset of range samples which cover the beam width using

$x_{\min }=R_{\hat{n}} \sin \left(-\gamma-\Theta_{3 \mathrm{~dB}} / 2\right)$ and $x_{\max }=R_{\hat{n}} \sin (-\gamma+$ $\left.\Theta_{3 \mathrm{~dB}} / 2\right) . R_{\hat{n}}$ is the re-tracked range and $\Theta_{3 \mathrm{~dB}}=$ $1.1992^{\circ}$ is the across track antenna half power beam width.

- Determine all valid samples where $x_{\min } \leq x \leq x_{\max }$ and $C \geq 0.7$. The ground range $x$ is given as: $x=R \sin (\alpha)$.

- Starting from the first valid sample we re-track the waveform using the TFMRA. This results in the final re-tracked position $\hat{n}_{\text {TFMRA }}$.

- Finally the slope-corrected Geo-referenced POCA position (latitude, longitude, elevation), shifted up-slope in across track direction, is determined using the orbital position, the velocity vector, the range and phase at the re-tracked position $R_{\hat{n}_{\text {TFMRA }}}, \Delta \phi_{\hat{n}_{\text {TFMRA }}}$ and some trigonometry considering the Earth's curvature (Wingham et al., 2004). 


\section{A3 Uncertainty of the DEM}

To derive the uncertainty map of the DEM the approach previously published by Griggs and Bamber (2009) was followed with some modifications. ICESat elevations of the three campaigns $3 \mathrm{~F}, 3 \mathrm{G}$ and $3 \mathrm{H}$ served as reference data. As a first step the elevation change at the ICESat position using bi-linear interpolation is derived from the ICESat $\mathrm{d} h / \mathrm{d} t$ raster obtained in Sect. 2.4. Then each ICESat elevation is corrected for elevation change which occurred between the individual ICESat observation and the reference time for the DEM, which is 1st July 2012. For the correction we assume a constant elevation change rate. This corrects the ICESat elevations at least partly in regions of large elevation change. For example, at PIG we observe elevation change of $2 \mathrm{~m} \mathrm{yr}^{-1}$ which adds up to an elevation change of more than $10 \mathrm{~m}$ within the last 6 years. After the correction most of the $10 \mathrm{~m}$ are reduced. The corrected ICESat elevation data sets serves as reference. Next the elevation difference $(\delta h)$ between the DEM and the reference data set were determined using bilinear interpolation. To derive the uncertainty grid we follow the assumption that the uncertainty depends on the parameters surface roughness, surface slope, number of data points $(N)$ used for interpolation and its standard deviation (SD). For each of the 4 parameters we derived separate raster data sets. Slope and roughness raster are directly obtained from the DEM. The slope is derived as gradient from a smoothed DEM using a kernel of $20 \mathrm{~km}$. The roughness is derived as the difference of the DEM from the smoothed DEM. $20 \mathrm{~km}$ was chosen to represent the beam limited footprint size and thus to give an indication of the footprint roughness. The $N$ raster is determined by counting all data points lying closer than a radius $R$ to each grid cell and SD is the standard deviation of those points. $R$ is set to $6 \mathrm{~km}$, the radius which was used for the DEM generation. For all four raster sets we derive the grid values at the ICESat positions using bilinear interpolation. Subsequently, all elevation differences are binned w.r.t. each of the four parameters. For example, the slope is divided into 200 bins with an increment of $0.01^{\circ}$ ranging from $0^{\circ}$ to $2^{\circ}$. For each bin the median and mean, as well as the standard deviation of the corresponding $\delta h$ values, is determined. This procedure is repeated for the other three parameters using a bin increment of $0.11 \mathrm{~m}$ for SD, $0.025 \mathrm{~m}$ for the roughness and 40 points for $N$, respectively, always starting with zero. As consequence we derive four $\delta h$ distributions. To each of the distributions a higher order polynomial of the order of 8 is fitted. This polynomial fit is applied using different measurement errors (ME) for each of the binned $\delta h$ values. The ME are derived from the corresponding standard deviations of each bin, as explained above. $\mathrm{ME}$ are low at low slope, low roughness, low SD and large $N$ (coefficients are listed in Tables A1 and A2). This kind of weighting and the high polynomial order ensures small residuals of the fit in bins with a small ME, reflecting areas of low slope such as flat ice sheet interiors. As a next step
Table A1. Polynomial fit coefficients and weights used for the Greenland uncertainty grid.

\begin{tabular}{lrrrr}
\hline Coefficient & Slope & SD & Roughness & $N$ \\
\hline C0 & 0.19 & 0.11 & 0.20 & 24.29 \\
C1 & -1.94 & 0.12 & -1.83 & -1.73 \\
C2 & 10.73 & -0.06 & 12.21 & 0.07 \\
C3 & 17.75 & 0.01 & -16.13 & -0.002 \\
C4 & -36.21 & -0.001 & 10.8 & $2.1 \times 10^{-5}$ \\
C5 & -21.80 & $4.2 \times 10^{-5}$ & -4.06 & $-1.7 \times 10^{-7}$ \\
C6 & 64.45 & $-9.7 \times 10^{-7}$ & 0.87 & $8.1 \times 10^{-10}$ \\
C7 & -37.48 & $1.2 \times 10^{-8}$ & -0.1 & $-2.1 \times 10^{-12}$ \\
C8 & 6.95 & $-6.0 \times 10^{-11}$ & 0.004 & $2.2 \times 10^{-15}$ \\
\hline Weights & 0.14 & 0.32 & 0.26 & 0.28 \\
\hline
\end{tabular}

the polynomial coefficients together with the values of the four raster data sets are used to derive four independent uncertainty grids. Finally, a combined uncertainty grid is determined using a weighted average of the four grids, presented for Antarctica and Greenland in Figs. A1 and A2, respectively. The weighting factors are gained from standard deviation $(\sigma)$ of the residuals between data and the polynomial fit (see Tables A1 and A2). Higher weights are given to the uncertainty raster with a smaller $\sigma$. Hence, the combined uncertainty of the DEM is then given as

$\varepsilon_{h}=\sum_{i=1}^{4} W_{i} \varepsilon_{i}$

with

$$
\begin{aligned}
\varepsilon_{i} & =C_{i_{0}}+C_{i_{1}} x_{i}+C_{i_{2}} x_{i}^{2}+C_{i_{3}} x_{i}^{3}+C_{i_{4}} x_{i}^{4}+C_{i_{5}} x_{i}^{5} \\
& +C_{i_{6}} x_{i}^{6}+C_{i_{7}} x_{i}^{7}+C_{i_{8}} x_{i}^{8} ;
\end{aligned}
$$

$C_{i_{0-8}}$ are the coefficients for each of the four polynomial fits given in Tables $\mathrm{A} 1$ and $\mathrm{A} 2 . W_{i}$ is the weighting factor and $i$ is the independent source of uncertainty $\left(i=1\right.$ then $x_{i}$ is the slope; $i=2$ then $x_{i}$ is the standard deviation of $h$ within one grid cell; $i=3$ then $x_{i}$ is the roughness; $i=4$ then $x_{i}$ is the number of points $N$ within one grid cell). $W_{i}$ is derived as follows:

$W_{i}=\frac{1}{S_{i} \sum_{i=1}^{4} \frac{1}{S_{i}}}$,

with the scaling factor $S$ :

$$
S_{i}=\frac{\sigma_{i}}{\sum_{i=1}^{4} \sigma_{i}} .
$$

\section{A4 Uncertainty of $\mathrm{d} h / \mathrm{d} t$}

The method to determine the final $\dot{h}=\mathrm{d} h / \mathrm{d} t$ grid consists of two steps. First the area of the entire ice sheet is divided 
Table A2. Polynomial fit coefficients and weights used for the Antarctica uncertainty grid.

\begin{tabular}{lrrrr}
\hline Coefficient & Slope & SD & Roughness & $N$ \\
\hline C0 & 0.80 & 0.28 & 0.41 & 22.51 \\
C1 & -19.38 & -0.11 & -5.25 & -0.03 \\
C2 & 159.65 & 0.89 & 22.32 & $1.8 \times 10^{-5}$ \\
C3 & -463.68 & -0.31 & -28.22 & $-4.5 \times 10^{-9}$ \\
C4 & 771.29 & 0.054 & 18.6 & $4.1 \times 10^{-13}$ \\
C5 & -762.50 & -0.004 & -6.95 & $4.0 \times 10^{-17}$ \\
C6 & 436.24 & $1.0 \times 10^{-4}$ & 1.49 & $-1.3 \times 10^{-20}$ \\
C7 & -132.31 & $-2.2 \times 10^{-6}$ & -0.17 & $1.1 \times 10^{-24}$ \\
C8 & 16.39 & $7.7 \times 10^{-9}$ & 0.008 & $-3.2 \times 10^{-29}$ \\
\hline Weights & 0.17 & 0.16 & 0.39 & 0.28 \\
\hline
\end{tabular}

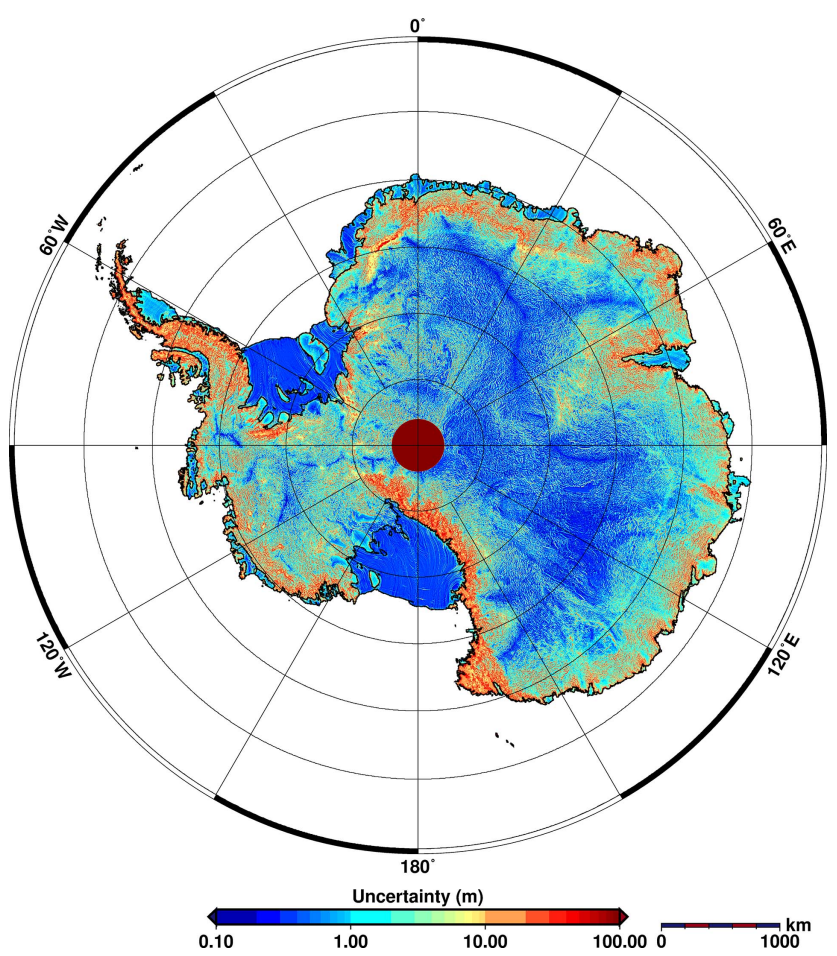

Figure A1. Uncertainty map of the new Antarctica DEM calculated using a multiple regression approach based on DEM-ICESat differences.

into a grid with a pixel spacing of $500 \mathrm{~m}$. For each pixel (indices $k, l) \dot{h}$ is estimated using a linear regression of $N 1_{k, l}$ topographic corrected elevation measurements $h_{\text {corr }_{i}}$ acquired at the time $t_{i} . N 1_{k, l}$ is the number of all $h_{\text {corr }_{i}}$ within $1 \mathrm{~km}$ distance to the corresponding pixel. $h_{\text {corr }_{i}}$ means that each elevation measurement $h_{i}$ is corrected for local topography by subtracting a reference elevation $\mathrm{DEM}_{i}$ which is derived from the new DEMs $\left(h_{\text {corr }_{i}}=h_{i}-\mathrm{DEM}_{i}\right)$. In the second step we derive the final interpolated $\dot{h}$ grid with a pixel size of $1 \mathrm{~km}$ using a block-mean and a radius of $25 \mathrm{~km}$. To derive the uncertainty map $\left(\varepsilon_{\dot{h}_{i}}\right)$ of the $\dot{h}$ grid two methods are applied. The first method uses the standard deviation of the mean for

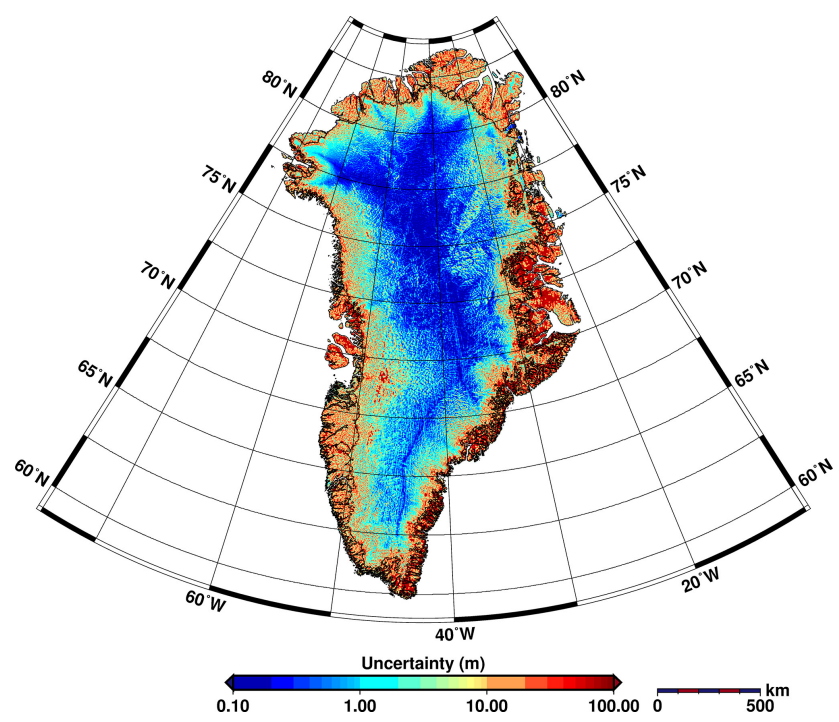

Figure A2. Uncertainty map of the new Greenland DEM calculated using a multiple regression approach based on DEM-ICESat differences.

each pixel.

$\varepsilon_{\dot{h}}=\frac{\sigma}{\sqrt{N 2}}$

$N 2_{m, n}$ is the number of all $\dot{h}$ values of the first grid falling within the search radius of $25 \mathrm{~km}$ of the corresponding final pixel with indices $m, n . \sigma$ is the standard deviation of the $N 2$ values. The results of this method are not shown here, but they are similar to the second method.

In the second method we propagate the error of each single elevation measurement $h_{i}$ through the two step process to derive the final $\varepsilon_{\dot{h}}$ grid. As mentioned above the approach to determine the first $\dot{h}$ grid is based on a least square fit to the $N 1$ topographic corrected elevation measurements $h_{\text {corr }_{i}}$ acquired at the time $t_{i}$ :

$h_{\mathrm{corr}_{i}}=\alpha_{0}+\alpha_{1} t_{i}$

Since we are interested in the uncertainty of $\dot{h}=\alpha_{1}$ we reorder the equation:

$$
\begin{aligned}
\dot{h} & =h_{\text {corr }_{i}} / t_{i} \\
& =\left(h_{i}-h_{\mathrm{DEM}_{i}}\right) / t_{i} \\
& =\left(\operatorname{Orb}_{i}-R_{i}-\mathrm{DEM}_{i}\right) / t_{i} \\
& =\left(\operatorname{Orb}_{i}-R_{i}+R_{\text {slope }_{i}}-\mathrm{DEM}_{i}\right) / t_{i}
\end{aligned}
$$

$\mathrm{Orb}_{i}$ is the altitude of CryoSat-2, $R_{i}$ the re-tracked range, $R_{\text {slope }_{i}}$ the applied slope correction at $t_{i}$. With the Gaussian error propagation we derive the following:

$$
\varepsilon_{\dot{h}_{k, l}}=\frac{1}{N 1_{k, l}}\left(\sum_{i=1}^{N_{1}}\left(\frac{\varepsilon_{\mathrm{Orb}_{i}}^{2}}{\mathrm{~d} t_{i}^{2}}+\frac{\varepsilon_{R_{i}}^{2}}{\mathrm{~d} t_{i}^{2}}+\frac{\varepsilon_{R_{\mathrm{slop} e_{i}}}^{2}}{\mathrm{~d} t_{i}^{2}}+\frac{\varepsilon_{\mathrm{DEM}_{i}}^{2}}{\mathrm{~d} t_{i}^{2}}\right)\right)^{1 / 2},
$$




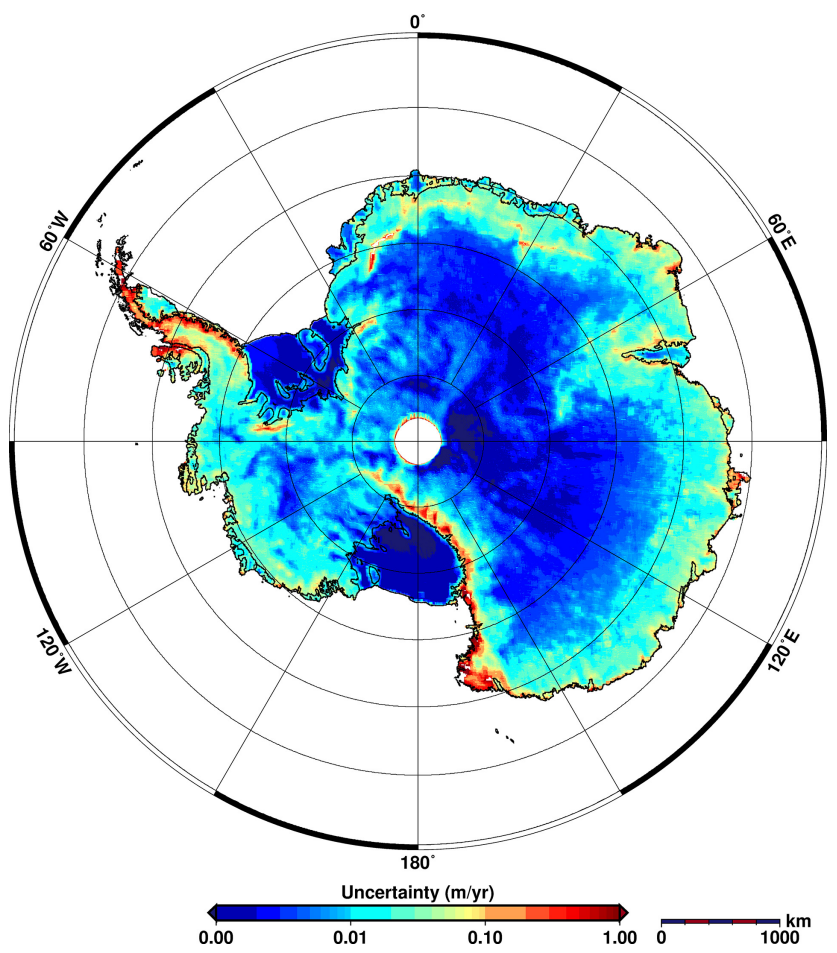

Figure A3. Uncertainty map of elevation change of Antarctica derived from error propagation. Clearly indicated are the high uncertainties at the steep margins.

where $\mathrm{d} t_{i}^{2}$ is the time period covered by the $N 1_{k, l}$ elevation measurements contributing to the regression at pixel $k, l$. $\varepsilon_{\mathrm{Orb}_{i}}$ is the uncertainty of the orbit, $\varepsilon_{R_{i}}$ the uncertainty of the range measurement, $\varepsilon_{R_{\text {slope }_{i}}}$ the uncertainty of the applied slope correction, and $\varepsilon_{\mathrm{DEM}_{i}}$ the uncertainty of the topographic correction. $\varepsilon_{R_{i}}$ is a composite of radar speckle $\left(\varepsilon_{\text {speckle }}\right)$, uncertainty of re-tracking $\left(\varepsilon_{\text {retr }}\right)$, uncertainty of the applied geophysical corrections ( $\left.\varepsilon_{\text {gcorr }}\right)$, and the uncertainty based on the variation of radar penetration ( $\left.\varepsilon_{\text {penetration }}\right)$.

$\varepsilon_{R_{i}}^{2}=\varepsilon_{\text {speckle }}^{2}+\varepsilon_{\text {retr }}^{2}+\varepsilon_{\text {gcorr }}^{2}+\varepsilon_{\text {penetration }}^{2}$

All those contributions and $\varepsilon_{\mathrm{Orb}_{i}}$ are assumed to be uncorrelated and constant in time and space (Table A3). With $\varepsilon_{\text {const }}^{2}=\varepsilon_{R_{i}}^{2}+\varepsilon_{\mathrm{Orb}_{i}}^{2}$ and $\mathrm{d} t_{k, l}=\mathrm{d} t_{i}$, since it is the same for each $i$ at the Pixel position $k, l$, we derive the following:

$\varepsilon_{\dot{h}_{k, l}}=\frac{1}{N 1_{k, l} \mathrm{~d} t_{k, l}}\left[N 1_{k, l} \varepsilon_{\text {const }}^{2}+\sum_{i=1}^{N 1_{k, l}}\left(\varepsilon_{R_{\text {slop }_{i}}}^{2}+\varepsilon_{\mathrm{DEM}_{i}}^{2}\right)\right]^{1 / 2}$.

The covered time period differs from pixel to pixel as well as the uncertainties for the slope and topographic correction are varying in space. We assume them as uncorrelated. Both are derived from uncertainty grids using bi-linear interpolation. The $\varepsilon_{\mathrm{DEM}_{i}}$ is taken from the DEM uncertainty grid presented in the section before. $\varepsilon_{R_{\text {slope }_{i}}}$ is derived from an CryoSat-2 elevation uncertainty grid. The latter grid was derived by

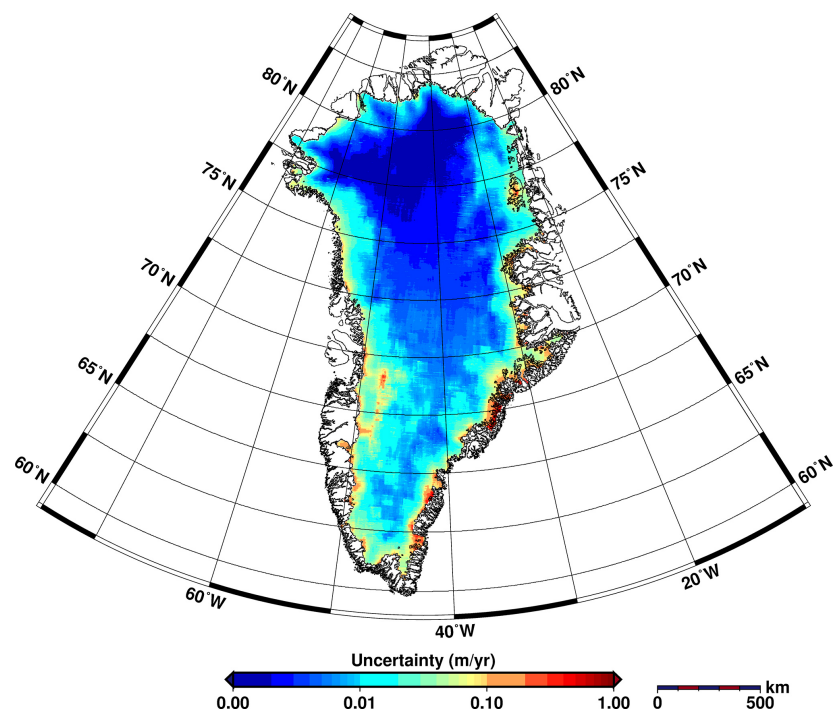

Figure A4. Uncertainty map of elevation change of Greenland derived from error propagation. Clearly indicated are the high uncertainties at the steep margins.

Table A3. Assumed uncertainty contribution to a single Range measurement. The speckle is estimated by Wingham et al. (2006) to be $0.16 \mathrm{~m}$ and the geophysical corrections, including the ionosphere and the dry and wet troposphere, are in total within $0.04 \mathrm{~m}$ over the ice sheets (E. Schrama, personal communication, 2014).

\begin{tabular}{ccccc}
\hline$\varepsilon_{\text {Orb }}$ & $\varepsilon_{\text {speckle }}$ & $\varepsilon_{\text {retr }}$ & $\varepsilon_{\text {gcorr }}$ & $\varepsilon_{\text {penetration }}$ \\
\hline $0.03 \mathrm{~m}$ & $0.16 \mathrm{~m}$ & $0.20 \mathrm{~m}$ & $0.04 \mathrm{~m}$ & $0.50 \mathrm{~m}$
\end{tabular}

applying the polynomial approach of Sect. A3 to the slope dependent uncertainty derived from the cross point analysis of ICESat data and CryoSat-2 data (see blue diamonds in Fig. 9).

Finally, the uncertainty grid $\varepsilon_{\dot{h}}$ of the final interpolated $\dot{h}$ product is obtained using Gaussian error propagation of the mean value of all $N 2_{m, n} \varepsilon_{\dot{h}}$ values lying within the $25 \mathrm{~km}$ radius of each pixel position $m, n$ :

$\varepsilon_{\dot{h}_{m, n}}=\frac{1}{N 2_{m, n}} \sqrt{\sum_{j=1}^{N_{2_{m, n}}} \varepsilon_{\dot{h}_{j}}^{2}}$

The resulting uncertainty maps of elevation change $\left(\varepsilon_{\dot{h}}\right)$ of the error propagation method are shown for both ice sheets in Figs. A3 and A4, respectively. Both methods produced similar uncertainty estimates. They show low uncertainties in low sloped areas with high data coverage and high uncertainties at the steeper margins with larger track spacing and higher DEM uncertainties. Differences are seen at the slightly sloped margins around Antarctica, with higher values derived from the second method. Finally we derive the uncertainties for the Antarctic Peninsula (AP), West 
Antarctica (WAI), East Antarctica (EAI), Greenland and Antarctica (AI) given in Table 4 by integrating all corresponding pixel $\varepsilon_{\dot{h}}$ of the uncertainty grid obtained with the second. We found that integrated uncertainties for both ice sheets are slightly larger with the second method. For the integration we used the drainage systems of Greenland and Antarctica provided by Zwally et al. (2012). If we assume that basin wide uncertainties are uncorrelated the uncertainty of the Antarctic Ice Sheet (AI) can be estimated as follows: $\varepsilon_{\dot{h}_{\mathrm{AI}}}=\sqrt{\varepsilon_{\dot{h}_{\mathrm{AP}}}^{2}+\varepsilon_{\dot{h}_{\mathrm{EAI}}}^{2}+\varepsilon_{\dot{h}_{\mathrm{WAI}}}^{2}}$. This results in $65 \mathrm{~km}^{3} \mathrm{yr}^{-1}$ compared to $83 \mathrm{~km}^{3} \mathrm{yr}^{-1}$ as given in Table 4. If we follow this approach and divide EAI, WAI and AP to the 27 drainage systems the uncertainty can easily be reduced further. Therefore our estimates which are given in Table 4 are rather upper bounds. 
Acknowledgements. The German Ministry of Economics and Technology (grant 50EE1008 to V. Helm) has supported this work. We thank Heiko Ewert (TU Dresden) for providing the inter-campaign offsets of ICESat. Furthermore, we thank Robert Cullen and Marco Fonari from ESA for their support in issues regarding the quality of CryoSat- 2 data. L. Padman and L. Erofeeva kindly provided the tide model CATS and supported us in the evaluation of issues at the grounding line. We thank Thomas Flament and the two anonymous reviewers and the editor for their comments.

Edited by: J. L. Bamber

\section{References}

Armitage, T., Wingham, D., and Ridout, A.: Meteorological origin of the static crossover pattern present in low-resolution-mode CryoSat-2 data over Central Antarctica, IEEE Geosci. Remote S., 11, 1295-1299, doi:10.1109/LGRS.2013.2292821, 2013.

Bamber, J. and Gomez-Dans, J. L.: The accuracy of digital elevation models of the Antarctic continent, Earth Planet. Sc. Lett., 237, 516-523, doi:10.1016/j.eps1.2005.06.008, 2005.

Bamber, J. L., Gomez-Dans, J. L., and Griggs, J. A.: A new 1 km digital elevation model of the Antarctic derived from combined satellite radar and laser data - Part 1: Data and methods, The Cryosphere, 3, 101-111, doi:10.5194/tc-3-101-2009, 2009.

Bamber, J. L., Griggs, J. A., Hurkmans, R. T. W. L., Dowdeswell, J. A., Gogineni, S. P., Howat, I., Mouginot, J., Paden, J., Palmer, S., Rignot, E., and Steinhage, D.: A new bed elevation data-set for Greenland, The Cryosphere, 7, 499-510, doi:10.5194/tc-7-499-2013, 2013.

Blair, J. B. and Hofton, M.: IceBridge LVIS L2 Geo-located Surface Elevation Product, 2010, updated 2012.

Boening, C., Lebsock, M., Landerer, F., and Stephens, G.: Snowfalldriven mass change on the East Antarctic ice sheet, Geophys. Res. Lett., 39, L21501, doi:10.1029/2012GL053316, 2012.

Borsa, A. A., Moholdt, G., Fricker, H. A., and Brunt, K. M.: A range correction for ICESat and its potential impact on ice-sheet mass balance studies, The Cryosphere, 8, 345-357, doi:10.5194/tc-8345-2014, 2014.

Bouzinac, C.: CryoSat Product Handbook, Tech. rep., European Space Agency, 2014.

Brenner, A., DiMarzio, J., and Zwally, H.: Precision and accuracy of satellite radar and laser altimeter data over the continental ice sheets, IEEE T. Geosci. Remote, 45, 321-331, doi:10.1109/TGRS.2006.887172, 2007.

Brenner, A. C., Bindschadler, R. A., Thomas, R. H., and Zwally, H. J.: Slope-induced errors in radar altimetry over continental ice sheets, J. Geophy. Res., 88, 1617-1623, 1983.

Csatho, B., Schenk, T., Van Der Veen, C., and Krabill, W. B.: Intermittent thinning of Jakobshavn Isbræ, West Greenland, since the Little Ice Age, J. Glaciol., 54, 131-144, doi:10.3189/002214308784409035, 2008.

Davis, C.: A robust threshold re-tracking algorithm for measuring ice-sheet surface elevation change from satellite radar altimeters, IEEE T. Geosci. Remote, 35, 974-979, doi:10.1109/36.602540, 1997.
Deutsch, C. V. and Journel, A.: GSLIB: Geostatistical Software Library and User's Guide, Oxford University Press, New York, 1992.

DiMarzio, J., Brenner, A., Schutz, R., Shuman, C. A., and Zwally, H. J.: GLAS/ICESat $1 \mathrm{~km}$ laser altimetry digital elevation model of Greenland, 2007.

ESA: CryoSat Data Quality Status Summary, Tech. Rep. CS-TNESA-GS-808 Version 7, European Space Agency, 2014.

Ewert, H., Popov, S. V., Richter, A., Schwabe, J., Scheinert, M., and Dietrich, R.: Precise analysis of ICESat altimetry data and assessment of the hydrostatic equilibrium for sub-glacial Lake Vostok, East Antarctica, Geophys. J. Int., 191, 557-568, doi:10.1111/j.1365-246X.2012.05649.x, 2012a.

Ewert, H., Groh, A., and Dietrich, R.: Volume and mass changes of the Greenland ice sheet inferred from ICESat and GRACE, J. Geodyn., 59-60, 111-123, doi:10.1016/j.jog.2011.06.003, 2012b.

Flament, T. and Rémy, F.: Dynamic thinning of Antarctic glaciers from along-track repeat radar altimetry, J. Glaciol., 58, 830-840, doi:10.3189/2012JoG11J118, 2012.

Fretwell, P., Pritchard, H. D., Vaughan, D. G., Bamber, J. L., Barrand, N. E., Bell, R., Bianchi, C., Bingham, R. G., Blankenship, D. D., Casassa, G., Catania, G., Callens, D., Conway, H., Cook, A. J., Corr, H. F. J., Damaske, D., Damm, V., Ferraccioli, F., Forsberg, R., Fujita, S., Gim, Y., Gogineni, P., Griggs, J. A., Hindmarsh, R. C. A., Holmlund, P., Holt, J. W., Jacobel, R. W., Jenkins, A., Jokat, W., Jordan, T., King, E. C., Kohler, J., Krabill, W., Riger-Kusk, M., Langley, K. A., Leitchenkov, G., Leuschen, C., Luyendyk, B. P., Matsuoka, K., Mouginot, J., Nitsche, F. O., Nogi, Y., Nost, O. A., Popov, S. V., Rignot, E., Rippin, D. M., Rivera, A., Roberts, J., Ross, N., Siegert, M. J., Smith, A. M., Steinhage, D., Studinger, M., Sun, B., Tinto, B. K., Welch, B. C., Wilson, D., Young, D. A., Xiangbin, C., and Zirizzotti, A.: Bedmap2: improved ice bed, surface and thickness datasets for Antarctica, The Cryosphere, 7, 375-393, doi:10.5194/tc-7-375-2013, 2013.

Fricker, H. A.: Assessment of ICESat performance at the salar de Uyuni, Bolivia, Geophys. Res. Lett., 32, L21S06, doi:10.1029/2005GL023423, 2005.

Fujita, S., Holmlund, P., Andersson, I., Brown, I., Enomoto, H., Fujii, Y., Fujita, K., Fukui, K., Furukawa, T., Hansson, M., Hara, K., Hoshina, Y., Igarashi, M., Iizuka, Y., Imura, S., Ingvander, S., Karlin, T., Motoyama, H., Nakazawa, F., Oerter, H., Sjöberg, L. E., Sugiyama, S., Surdyk, S., Ström, J., Uemura, R., and Wilhelms, F.: Spatial and temporal variability of snow accumulation rate on the East Antarctic ice divide between Dome Fuji and EPICA DML, The Cryosphere, 5, 1057-1081, doi:10.5194/tc-5-1057-2011, 2011.

Galin, N., Wingham, D. J., Cullen, R., Fornari, M., Smith, W. H. F., and Abdalla, S.: Calibration of the CryoSat-2 interferometer and measurement of across-track ocean slope, IEEE T. Geosci. Remote, 51, 57-72, doi:10.1109/TGRS.2012.2200298, 2013.

Griggs, J. A. and Bamber, J. L.: A new 1 km digital elevation model of Antarctica derived from combined radar and laser data - Part 2: Validation and error estimates, The Cryosphere, 3, 113-123, doi:10.5194/tc-3-113-2009, 2009.

Groh, A., Ewert, H., Rosenau, R., Fagiolini, E., Gruber, C., Floricioiu, D., Abdel Jaber, W., Linow, S., Flechtner, F., Eineder, M., Dierking, W., and Dietrich, R.: Mass, Volume and Velocity of 
the Antarctic Ice Sheet: Present-Day Changes and Error Effects, Surv. Geophys., 1-25, doi:10.1007/s10712-014-9286-y, 2014.

Haran, T., Bohlander, J., Scambos, T., and Fahnestock, M.: MODIS mosaic of Antarctica (MOA) image map, Digital media, National Snow and Ice Data Center, Boulder, CO, USA, 2005.

Howat, I. M., Negrete, A., and Smith, B. E.: The Greenland Ice Mapping Project (GIMP) land classification and surface elevation datasets, The Cryosphere Discuss., 8, 453-478, doi:10.5194/tcd-8-453-2014, 2014.

Hurkmans, R. T. W. L., Bamber, J. L., and Griggs, J. A.: Brief communication "Importance of slope-induced error correction in volume change estimates from radar altimetry", The Cryosphere, 6, 447-451, doi:10.5194/tc-6-447-2012, 2012a.

Hurkmans, R. T. W. L., Bamber, J. L., Sørensen, L. S., Joughin, I. R., Davis, C. H., and Krabill, W. B.: Spatiotemporal interpolation of elevation changes derived from satellite altimetry for Jakobshavn Isbræ, Greenland, J. Geophys. Res.-Earth, 117, F03001, doi:10.1029/2011JF002072, 2012b.

Isaaks, E. H. and Srivastava, R. M.: An Introduction to Applied Geostatistics, Oxford University Press, New York, 1989.

Jensen, J. R.: Angle measurement with a phase monopulse radar altimeter, IEEE T. Antenn. Propag., 47, 715-724, 1999.

Joughin, I. and Bamber, J. L.: Thickening of the ice stream catchments feeding the Filchner-Ronne Ice Shelf, Antarctica, Geophys. Res. Lett., 32, L17503, doi:10.1029/2005GL023844, 2005.

Joughin, I., Smith, B. E., and Abdalati, W.: Glaciological advances made with interferometric synthetic aperture radar, J. Glaciol., 56, 1026-1042, doi:10.3189/002214311796406158, 2010a.

Joughin, I., Smith, B. E., Howat, I. M., Scambos, T., and Moon, T.: Greenland flow variability from icesheet-wide velocity mapping, J. Glaciol., 56, 415-430, doi:10.3189/002214310792447734, 2010b.

Khan, S., Kjaer, K., Bevis, M., Bamber, J., Wahr, J., Kjeldsen, K., Bjørk, A., Korsgaard, N., Stearns, L., van den Broeke, M., Liu, L., Larsen, N., and Muresan, I.: Sustained mass loss of the Northeast Greenland ice sheet triggered by regional warming, Nature Climate Change, 4, 292-299, doi:10.1038/nclimate2161, 2014.

Krabill, W. B.: IceBridge ATM L2 Icessn Elevation, Slope, and Roughness. Version 2, [indicate subset used], 2014.

Kwok, R., Cunningham, G. F., Zwally, H. J., and Yi, D.: Ice, Cloud, and land Elevation Satellite (ICESat) over Arctic sea ice: retrieval of freeboard, J. Geophys. Res., 112, C12013, doi:10.1029/2006JC003978, 2007.

Lambrecht, A., Mayer, C., Oerter, H., and Nixdorf, U.: Investigations of the mass balance of the southeastern Ronne Ice Shelf, Antarctica, Ann. Glaciol., 29, 250-254, doi:10.3189/172756499781820996, 1999.

Legresy, B., Papa, F., Remy, F., Vinay, G., van den Bosch, M., and Zanife, O. Z.: ENVISAT radar altimeter measurements over continental surfaces and ice caps using the ICE-2 retracking algorithm, Remote Sens. Environ., 95, 150-163, 2005.

Lenaerts, J. T. M., van Meijgaard, E., van den Broeke, M. R., Ligtenberg, S. R. M., Horwath, M., and Isaksson, E.: Recent snowfall anomalies in Dronning Maud Land, East Antarctica, in a historical and future climate perspective, Geophys. Res. Lett., 40, 2684-2688, doi:10.1002/grl.50559, 2013.
Liu, H., Jezek, K. C., Li, B., and Zhao, Z.: Radarsat Antarctic Mapping Project Digital Elevation Model Version 2, Digital media, National Snow and Ice Data Center, Boulder, CO, USA, 2001.

McMillan, M., Shepherd, A., Sundal, A., Briggs, K., Muir, A., Ridout, A., Hogg, A., and Wingham, D.: Increased ice losses from Antarctica detected by CryoSat-2, Geophys. Res. Lett., 41, 3899-3905, doi:10.1002/2014GL060111, 2014GL060111, 2014.

NASA: NASA GSFC Retracking Algorithms, available at: http://icesat4.gsfc.nasa.gov/radar_data/data_processing/ gsfcretrackdoc.960725.php (last access: 16 October 2013), 2006.

Padman, L., Fricker, H. A., Coleman, R., Howard, S., and Erofeeva, L.: A new tide model for the Antarctic ice shelves and seas, Ann. Glaciol., 34, 247-254, doi:10.3189/172756402781817752, 2002.

Padman, L., Erofeeva, S. Y., and Fricker, H. A.: Improving Antarctic tide models by assimilation of ICESat laser altimetry over ice shelves, Geophys. Res. Lett., 35, L21501, doi:10.1029/2008GL035592, 2008.

Pritchard, H. D., Arthern, R. J., Vaughan, D. G., and Edwards, L. A.: Extensive dynamic thinning on the margins of the Greenland and Antarctic ice sheets, Nature, 461, 447-558, doi:10.1038/nature08471, 2009.

Pritchard, H. D., Ligtenberg, S. R. M., Fricker, H. A., Vaughan, D. G., van den Broeke, M. R., and Padman, L.: Antarctic icesheet loss driven by basal melting of ice shelves, Nature, 484 , 502-505, doi:10.1038/nature10968, 2012.

Remy, F., Mazzega, P., Houry, S., Brossier, C., and Minster, J.: Mapping of the Topography of Continental Ice by Inversion of Satellite-Altimeter Data, J. Glaciol., 35, 98-107, doi:10.3189/002214389793701419, 1989.

Retzlaff, R. and Bentley, C. R.: Timing of stagnation of Ice Stream $\mathrm{C}$, West Antarctica, from short-pulse radar studies of buried surface crevasses, J. Glaciol., 39, 553-561, 1993.

Rignot, E.: Mass balance of East Antarctic glaciers and ice shelves from satellite data, Ann. Glaciol., 34, 217-227, doi:10.3189/172756402781817419, 2002.

Rignot, E. and Kanagaratnam, P.: Changes in the velocity structure of the Greenland Ice Sheet, Science, 311, 986-990, 2006.

Rignot, E., Velicogna, I., van den Broeke, M. R., Monaghan, A., and Lenaerts, J. T. M.: Acceleration of the contribution of the Greenland and Antarctic ice sheets to sea level rise, Geophys. Res. Lett., 38, L05503, doi:10.1029/2011GL046583, 2011.

Roemer, S., Legresy, B., Horwath, M., and Dietrich, R.: Refined analysis of radar altimetry data applied to the region of the subglacial Lake Vostok/Antarctica, Remote Sens. Environ., 106, 269-284, 2007.

Rose, K.: Characteristics of ice flow in Marie Byrd Land, Antarctica, J. Glaciol., 24, 63-75, 1979.

Sandwell, D. and Smith, W.: Slope correction for ocean radar altimetry, J. Geodesy, 88, 765-771, doi:10.1007/s00190-0140720-1, 2014.

Scambos, T. A., Berthier, E., and Shuman, C. A.: The triggering of subglacial lake drainage during rapid glacier drawdown: Crane Glacier, Antarctic Peninsula, Ann. Glaciol., 52, 74-82, doi:10.3189/172756411799096204, 2011.

Scagliola, M.: CryoSat footprints, Tech. Rep. 1.2, Aresys, 2013. 
Scagliola, M. and Fornari, M.: Known biases in CryoSat Level1b products, Tech. rep., ESA, 2013.

Scott, J. B. T., Gudmundsson, G. H., Smith, A. M., Bingham, R. G., Pritchard, H. D., and Vaughan, D. G.: Increased rate of acceleration on Pine Island Glacier strongly coupled to changes in gravitational driving stress, The Cryosphere, 3, 125-131, doi:10.5194/tc-3-125-2009, 2009.

Sergienko, O. V., Creyts, T. T., and Hindmarsh, R. C. A.: Similarity of organized patterns in driving and basal stresses of Antarctic and Greenland ice sheets beneath extensive areas of basal sliding, Geophys. Res. Lett., 41, 3925-3932, doi:10.1002/2014GL059976, 2014.

Shepherd, A., Ivins, E. R., A, G., Barletta, V. R., Bentley, M. J., Bettadpur, S., Briggs, K. H., Bromwich, D. H., Forsberg, R., Galin, N., Horwath, M., Jacobs, S., Joughin, I., King, M. A., Lenaerts, J. T. M., Li, J., Ligtenberg, S. R. M., Luckman, A., Luthcke, S. B., McMillan, M., Meister, R., Milne, G., Mouginot, J., Muir, A., Nicolas, J. P., Paden, J., Payne, A. J., Pritchard, H., Rignot, E., Rott, H., Sørensen, L. S., Scambos, T. A., Scheuchl, B., Schrama, E. J. O., Smith, B., Sundal, A. V., van Angelen, J. H., van de Berg, W. J., van den Broeke, M. R., Vaughan, D. G., Velicogna, I., Wahr, J., Whitehouse, P. L., Wingham, D. J., Yi, D., Young, D., and Zwally, H. J.: A reconciled estimate of ice-sheet mass balance, Science, 338, 1183-1189, doi:10.1126/science.1228102, 2012.

Shi, H., Lu, Y., Bao, L., Du, Z., and Zhang, Z.: 2003-2008 ice sheet elevation change on the Lake Vostok, Antarctica, from ICESat, in: Education Technology and Training, 2008, and 2008 International Workshop on Geoscience and Remote Sensing, ETT and GRS 2008, 21-22 December 2008, Shanghai, China, Vol. 2, 561564, doi:10.1109/ETTandGRS.2008.279, 2008.

Shuman, C. A., Zwally, H. J., Schutz, B. E., Brenner, A. C., DiMarzio, J. P., Suchdeo, V. P., and Fricker, H. A.: ICESat Antarctic elevation data: preliminary precision and accuracy assessment, Geophys. Res. Lett., 33, L07501, doi:10.1029/2005GL025227, 2006.

Smith, A. M., Bentley, C. R., Bingham, R. G., and Jordan, T. A.: Rapid subglacial erosion beneath Pine Island Glacier, West Antarctica, Geophys. Res. Lett., 39, L12501, doi:10.1029/2012GL051651, 2012.

Smith, B. E., Fricker, H. A., Joughin, I. R., and Tulaczyk, S.: An inventory of active subglacial lakes in Antarctica detected by ICESat (2003-2008), J. Glaciol., 55, 573-595, doi:10.3189/002214309789470879, 2009.

Sørensen, L. S., Simonsen, S. B., Nielsen, K., Lucas-Picher, P., Spada, G., Adalgeirsdottir, G., Forsberg, R., and Hvidberg, C. S.: Mass balance of the Greenland ice sheet (2003-2008) from ICESat data - the impact of interpolation, sampling and firn density, The Cryosphere, 5, 173-186, doi:10.5194/tc-5-173-2011, 2011.

Tedesco, M., Fettweis, X., Mote, T., Wahr, J., Alexander, P., Box, J. E., and Wouters, B.: Evidence and analysis of 2012 Greenland records from spaceborne observations, a regional climate model and reanalysis data, The Cryosphere, 7, 615-630, doi:10.5194/tc-7-615-2013, 2013.
Thomas, R. H., Abdalati, W., Frederick, E., Krabill, W. B., Manizade, S., and Steffen, K.: Investigation of surface melting and dynamic thinning on Jakobshavn Isbræ, Greenland, J. Glaciol., 49, 231-239, doi:10.3189/172756503781830764, 2003.

Thomas, E. R., Marshall, G. J., and McConnell, J. R.: A doubling in snow accumulation in the western Antarctic Peninsula since 1850, Geophys. Res. Lett., 35, L01706, doi:10.1029/2007GL032529, 2008.

Thomas, R., Frederick, E., Krabill, W., Manizade, S., and Martin, C.: Recent changes on Greenland outlet glaciers, J. Glaciol., 55, 147-162, doi:10.3189/002214309788608958, 2009.

Wingham, D. J., Rapley, C. G., and Griffiths, H.: New techniques in satellite altimeter tracking systems, in: Proceedings of the IGARSS Symposium, vol. SP-254, 1339-1344, edited by: Guyenne, T. D. and Hunt, J. J., European Space Agency, Zurich, September 1986, 1986.

Wingham, D., Phalippou, L., Mavrocordatos, C., and Wallis, D.: The mean echo and echo cross product from a beamforming interferometric altimeter and their application to elevation measurement, IEEE T. Geosci. Remote, 42, 2305-2323, doi:10.1109/TGRS.2004.834352, 2004.

Wingham, D., Francis, C. R., Baker, S., Bouzinac, C., Cullen, R., de Chateau-Thierry, P., Laxon, S. W., Mallow, U., Mavrocordatos, C., Phalippou, L., Ratier, G., Rey, L., Rostan, F., Viau, P., and Wallis, D.: CryoSat: a mission to determine the fluctuations in earth's land and marine ice fields, Adv. Space Res., 37, 841-871, 2006a.

Wingham, D. J., Wallis, D. W., and Shepherd, A.: Spatial and temporal evolution of Pine Island Glacier thinning, 1995 to 2006 , Geophys. Res. Lett., 36, L17501, doi:10.1029/2009GL039126, 2009.

Zwally, H. J.: Correction to the ICESat data product surface elevations due to an error in the range determination from transmit-pulse reference-point selection (Centroid vs Gaussian), Tech. rep., NSIDC, http://nsidc.org/data/icesat/ correction-to-product-surface-elevations.html (last access: 12 November 2013), 2013.

Zwally, H. J., Jun, L., Brenner, A. C., Beckley, M., Cornejo, H. G., Dimarzio, J., Giovinetto, M. B., Neumann, T. A., Robbins, J., Saba, J. L., Donghui, Y., and Wang, W.: Greenland ice sheet mass balance: distribution of increased mass loss with climate warming; 2003-07 versus 1992-2002, J. Glaciol., 57, 88-102, 2011.

Zwally, H. J., Schutz, R., Bentley, C., Bufton, J., Herring, T., Minster, J., Spinhire, J., and Thomas, R.: GLAS/ICESat L2 Antarctic and Greenland Ice Sheet Altimetry Data, Version 33, [GLA12], available at: http://nsidc.org/data/gla12.html (last access: 25 March 2013), 2011.

Zwally, H. J., Giovinetto, M. B., Beckley, M. A., and Saba, J. J. L.: Antarctic and Greenland Drainage Systems, available at: http://icesat4.gsfc.nasa.gov/cryo_data/ant_ grn_drainage_systems.php (last access: 16 January 2014), 2012. 